\title{
Water vapour source impacts on oxygen isotope variability in tropical precipitation during Heinrich events
}

\author{
S. C. Lewis ${ }^{1}$, A. N. LeGrande ${ }^{2}$, M. Kelley ${ }^{2}$, and G. A. Schmidt ${ }^{2}$ \\ ${ }^{1}$ Research School of Earth Sciences, The Australian National University, ACT, 0200, Canberra, Australia \\ ${ }^{2}$ NASA Goddard Institute for Space Studies and Center for Climate Systems Research, Columbia University, \\ 2880 Broadway, New York, 10025, USA
}

Received: 18 January 2010 - Published in Clim. Past Discuss.: 10 February 2010

Revised: 3 May 2010 - Accepted: 5 May 2010 - Published: 1 June 2010

\begin{abstract}
Water isotope records such as speleothems provide extensive evidence of past tropical hydrological changes. During Heinrich events, isotopic changes in monsoon regions have been interpreted as implying a widespread drying through the Northern Hemisphere tropics and an antiphased precipitation response in the south. Here, we examine the sources of this variability using a water isotope-enabled general circulation model, Goddard Institute for Space Studies ModelE. We incorporate a new suite of vapour source distribution tracers to help constrain the impact of precipitation source region changes on the isotopic composition of precipitation and to identify nonlocal amount effects. We simulate a collapse of the North Atlantic meridional overturning circulation with a large freshwater input to the region as an idealised analogue to iceberg discharge during Heinrich events. An increase in monsoon intensity, defined by vertical wind shear, is modelled over the South American domain, with small decreases simulated over Asia. Simulated isotopic anomalies agree well with proxy climate records, with lighter isotopic values simulated over South America and enriched values across East Asia. For this particular abrupt climate event, we identify which climatic change is most likely linked to water isotope change - changes in local precipitation amount, monsoon intensity, water vapour source distributions or precipitation seasonality. We categorise individual sites according to the climate variability that water isotope changes are most closely associated with, and find that the dominant isotopic controls are not consistent across the tropics - simple local explanations, in particular, fall short of explaining water isotope variability at all sites. Instead, the best interpretations appear to be site specific and often regional in scale.
\end{abstract}

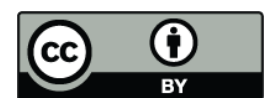

Correspondence to: S. C. Lewis (sophie.lewis@anu.edu.au)

\section{Introduction}

\subsection{Heinrich event expression in $\delta^{18} \mathrm{O}$ records}

The last glacial period was punctuated by successive Heinrich $(\mathrm{H})$ events, short-lived abrupt cool episodes around the North Atlantic (Heinrich, 1988). These events are defined by distinct foraminifera-free zones within ice-rafted debris layers in oceanic sediment cores; they are thought to result from massive, periodic iceberg discharges into the North Atlantic basin. Heinrich events were accompanied by strong sea surface temperature (SST) and salinity reductions in the North Atlantic (Bond et al., 1992).

In the North Atlantic, Heinrich events usually occur towards the end of a cycle of progressively cooler interstadials (Dansgaard-Oeschger cycles), which culminate in a prolonged cold period during which a Heinrich event occurs (Bond et al., 1993). Conversely, $\mathrm{H}$ events in the Antarctic are contemporaneous with warmer conditions, suggestive of a "bipolar seesaw" connection between the hemispheres (Broecker, 1998). During H events, regional sea surface density gradient changes likely resulted in a substantial decrease in the production of North Atlantic Deep Water (NADW) (Keigwin and Lehman, 1994). Significant regional climatic changes during $\mathrm{H}$ events are near-global in extent (Hemming, 2004).

In the low-latitudes, speleothem-based climate reconstructions show the monsoon regions respond abruptly during Heinrich events (Fig. 1). Oxygen isotope reconstructions from the East Asian monsoon (EAM) region demonstrate an anti-correlation with Greenland ice core records (Wang et al., 2001; Wang et al., 2008; Zhou et al., 2008). In China, enriched $\delta^{18} \mathrm{O}_{\text {calcite }}$ values ( $\delta$ in permil units, \%o, of the subscripted value relative to a known standard) coincident with $\mathrm{H}$ events have been interpreted as a weakening of the EAM (Wang et al., 2001). Brazilian speleothem $\delta^{18} \mathrm{O}$ records are characterised by a sequence of wet conditions synchronous

Published by Copernicus Publications on behalf of the European Geosciences Union. 


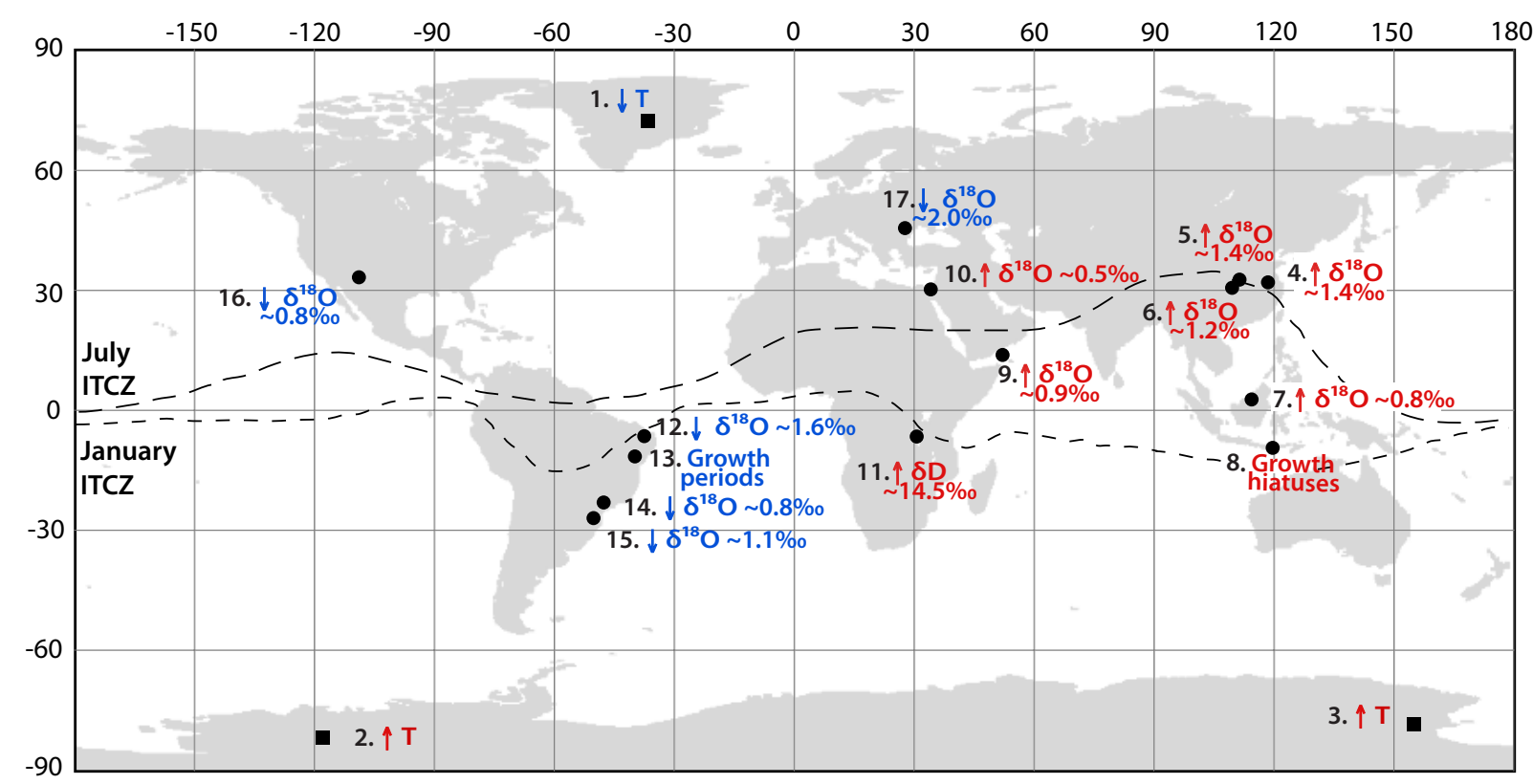

Fig. 1. Spatial pattern of climatic and $\delta^{18} \mathrm{O}$ changes during Heinrich events from selected proxy records. High-latitude sites (squares):

1. GRIP (Bond et al., 1993) - H1, H2, H3;

2. Byrd (Blunier et al., 1998) - H1, H2;

3. Taylor Dome (Indermühle et al., 2000; Grootes et al., 2001) - H3, H4;

Low-latitude speleothem sites (circles):

4. Hulu cave, China (Wang et al., 2001) - H1, H2, H3, H4;

5. Songjia cave, China (Zhou et al., 2008) - H1; 6. Sanbao cave, China (Wang et al., 2008) - H1;

7. Snail Shell and Bukit Assam caves, northern Borneo (Partin et al., 2007) - H1;

8. Liang Luar cave, Indonesia (Lewis et al., 2010) - H2, H3;

9. Moomi cave, Socotra, Yemen (Shakun et al., 2007) - H1, H5;

10. Soreq cave, Israel (Bar-Matthews et al., 1999) - H1, H2, H5;

11. Lake Tanganyika, East Africa (Tierney et al., 2008) - H1, H4;

12. Rio Grande do Norte, northeastern Brazil (Cruz et al., 2009) - H1, H2;

13. Toca da Boa Vista, northeastern Brazil (Wang et al., 2004) - H1, H4, H5, H6;

14. Santana cave, southern Brazil (Cruz et al., 2006b) - H1, H3, H4, H5, H6;

15. Botuverá cave, southern Brazil (Wang et al., 2006) - H2, H3 and (Cruz et al., 2006) - H1, H4, H5;

16. Cave of the Bells, Arizona, US (Wagner et al., 2010) - H4;

17. Poleva Cave, southwest Romania (Constantin et al., 2007) - H4.

Values indicate average change between Heinrich and baseline $\delta^{18} \mathrm{O}$ for all identifiable Heinrich events. The position of modern ITCZ during January and July is indicated.

with cold Heinrich events in the North Atlantic and periods of weak East Asian summer monsoon circulation in China (Wang et al., 2004, 2006; Cruz et al., 2006b; Cruz et al., 2009). Wang et al. (2006) propose a north-south precipitation anti-phasing across the hemispheres during $\mathrm{H}$ events under a southward shift of the intertropical convergence zone (ITCZ). Collectively, however, proxy reconstructions indicate a complex spatial pattern of hydrological changes beyond coherent north-south anti-phasing (Tierney et al., 2008; Wagner et al., 2010; Lewis et al., 2010). This study investigates the coherence of spatial patterns of tropical hydrological changes during $\mathrm{H}$ events.
A remaining uncertainty in the interpretation of tropical variability during $\mathrm{H}$ events is in the "monsoonal" climate change, which is widely used in palaeoclimatic literature to describe a variety of phenomena, including a seasonal reversal of upper or lower level zonal winds, the strong seasonality of tropical precipitation or hydrological changes resulting from ITCZ shifts. We aim to resolve, in part, this ambiguity in the meaning of climatic interpretations by describing which parts of the monsoon system are impacted by $\mathrm{H}$ events. 


\subsection{Previous modelling work}

Prior modelling studies have consistently demonstrated that freshwater input to the North Atlantic, analogous to iceberg discharge, reduces NADW formation and drives a regional cooling (Manabe and Stouffer, 2000; Stouffer et al., 2006). The simulated thermohaline circulation (THC) rapidly weakens following a freshwater perturbation, resulting in a reduction in northward heat and salt transport in the North Atlantic. The greatest temperature anomalies occur over the northern North Atlantic, with some cooling over Greenland, Europe and North America and a mild warming over parts of the Antarctic, as an expression of the bipolar seesaw. Prior studies also indicate significant modelled water isotope anomalies following an abrupt, though smaller, North Atlantic freshwater forcing (e.g. LeGrande et al., 2006). Water isotope responses include depletion in precipitation across the North Atlantic and southern subtropics, with enrichment to the north.

In the tropics, the impact of a simulated reduction in THC intensity includes a southward shift in precipitation bands and in the ITCZ over the tropical oceans (Dong and Sutton, 2002; Zhang and Delworth, 2005). Furthermore, a freshwater-forced reduction in the Atlantic meridional overturning circulation and expanded northern ice coverage drive extensive remote responses, including an El Niño-like SST pattern in the southeastern tropical Pacific. Overall, a freshwater-forced southward ITCZ shift, particularly over the Atlantic Ocean, is a robust response across multiple models (Stouffer et al., 2006).

\subsection{Sources of $\delta^{18} \mathrm{O}$ variability}

The $\delta^{18} \mathrm{O}$ in precipitation $\left(\delta^{18} \mathrm{O}_{p}\right)$ integrates changes in atmospheric circulation from source to the site of rainout (Noone, 2008). The dominant controls on $\delta^{18} \mathrm{O}$ are variable between proxy sites and include local precipitation amount variability together with changes in regional hydrology, the initial evaporative source, degree of rain-out during transit and atmospheric mixing.

Tropical $\delta^{18} \mathrm{O}$ variability is often interpreted as an alteration in local precipitation. This inference is based on simple Rayleigh distillation models that predict that isotope ratios in precipitation are correlated to local rainfall amount (the "amount effect" relationship) (Dansgaard, 1964; AraguásAraguás et al., 1998). In general circulation models (GCMs), however, mixing plays an important role and these modelling results indicate that the spatial amount effect relationship is strongest only over the tropical oceans, rather than the land surface where speleothem archives occur (Tindall et al., 2009), and on intraseasonal timescales or longer (Risi et al., 2008). Additionally, observational studies show the amount effect is most applicable at coastal locations (Rozanski et al., 1993).
Furthermore, modern spatial isotope-climate gradients between multiple sites may not be good predictors of temporal gradients (Schmidt et al., 2007; LeGrande and Schmidt, 2009). As such, simple $\delta^{18} \mathrm{O}$ interpretations based on this amount effect relationship alone are unlikely to be robust for all sites and the dominant $\delta^{18} \mathrm{O}_{p}$ control is likely to be spatially variable and site specific. In some cases $\delta^{18} \mathrm{O}_{p}$ changes might be more accurately interpreted in terms of regional hydrological changes (Vuille et al., 2005; Schmidt et al., 2007; LeGrande and Schmidt, 2009).

Source region effects are also an important $\delta^{18} \mathrm{O}_{p}$ control, through changes in initial vapour source composition and air mass transport distance (Rozanski et al., 1993). The relative amount of continental recycling is a determinant of $\delta^{18} \mathrm{O}_{p}$, as plant evapo-transpiration is non-fractionating and retains the composition of local groundwater, resulting in enriched values relative to oceanic derived precipitation (Zimmermann et al., 1967). Also, the location of the source region influences the extent of condensation undergone by a vapour parcel in transit to the site of precipitation. Locally derived vapour is typically relatively enriched, experiencing less condensation en route than water vapour transported over long distances (Rozanski et al., 1993). There have been various interpretations of $\delta^{18} \mathrm{O}$ variability in terms of source region effects (Jouzel and Koster, 1996; Masson-Delmotte et al., 2005).

As the relative contribution of vapour sources cannot be directly measured, model studies have demonstrated the importance of source region changes on $\delta^{18} \mathrm{O}_{p}$ (e.g. Koster et al., 1986; Cole et al., 1999). Studies incorporating back trajectory modelling of air mass parcels have shown the significance of source regions for seasonal $\delta^{18} \mathrm{O}_{p}$ compositions (Griffiths et al., 2009; Sjostrom and Welker, 2009). Also, source tracers from pre-specified regions ("painted water") have been employed as a GCM diagnostic tool in hydrological studies (Joussaume et al., 1986; Koster et al., 1986; Druyan and Koster, 1989) and in palaeotemperature reconstructions (Johnsen et al., 1989; Jouzel et al., 1997). Noone (2008), for example, considered the impact of multiple drivers of $\delta^{18} \mathrm{O}_{p}$ variability (initial source, transport pathway and atmospheric mixing) and showed that Antarctic isotopic records reflect changes in mid-latitude circulation. Precipitation source region tracers provide a useful diagnostic for identifying and classifying sites where isotopic variability is characterised by controls other than a clear local amount effect. In particular, source tracers provide a means of recognising both regional, nonlocal amount effect dominated localities and those where $\delta^{18} \mathrm{O}_{p}$ is controlled by distinct shifts in precipitation source.

In this study, we examine the relationship between tropical and high-latitude regions during Heinrich events, using a fully coupled water isotope-enabled atmosphere-ocean GCM. For speleothem sites within the Australian, Indian, EAM and South American (SM) monsoon regions we also use a novel set of Vapour Source Distribution (VSD) tracers, 
as well as water isotope tracers, as a set of diagnostic tools to assess the nature of $\delta^{18} \mathrm{O}_{p}$ changes during abrupt climatic excursions (i.e. "hosing"), analogous to an $\mathrm{H}$ event. We investigate whether the spatial pattern of modelled $\delta^{18} \mathrm{O}_{p}$ during Heinrich-like simulations can be attributed to changes in local precipitation amount, monsoon intensity (defined by zonal wind shear), precipitation source regions, or the seasonality of precipitation. Finally, we categorise proxy sites by type, according to the dominant controls on simulated isotopic variability.

\section{Methods}

\subsection{Model description}

Simulations were made using the coupled atmosphere-ocean GISS (Goddard Institute for Space Studies) ModelE-R. The horizontal resolution is $4^{\circ} \times 5^{\circ}$ with 20 vertical levels up to $0.1 \mathrm{hPa}$ in the atmosphere (Schmidt et al., 2006) and a 13 layer Russell ocean model of the same horizontal resolution (Hansen et al., 2007). Atmospheric advection uses the quadratic upstream scheme, with 9 moments advected in addition to mean quantities. The ocean component is nonBoussinesq, mass conserving and uses "natural" boundary conditions at the free surface. The addition of freshwater increases the free surface and reduces salinity through dilution. No equivalent salt fluxes or flux adjustments are used.

Water isotope tracers $\left({ }^{1} \mathrm{H}_{2}^{16} \mathrm{O}\right.$, "normal" water; ${ }^{2} \mathrm{H}^{1} \mathrm{H}^{16} \mathrm{O}$ or HDO, reported as $\delta \mathrm{D}$; and ${ }^{1} \mathrm{H}_{2}^{18} \mathrm{O}, \delta^{18} \mathrm{O}$ ) are incorporated into the atmosphere, land surface, sea ice and ocean. Water isotopes are tracked through all stages of the hydrologic cycle and are advected like water throughout the model, but at each phase change, a fractionation is applied, explicitly determining equilibrium fractionation and with parameterisations accounting for kinetic fractionations (Schmidt et al., 2005).

\subsection{Water vapour source distribution tracers}

The water source tracer methodology employed here is a generalisation of the regional source tracers ("painted water") approach (Koster et al., 1986) but requires no prior definition of regions (Kelley, 2003). We define a suite of VSD tracers in the model, and atmospheric transport and condensation processes alter these analogously to a non-fractionating water isotope tracer. The VSD is the integrated mass of water vapour in each model cell, expressed as an area integral of evaporative input unique to that cell. The VSD can be represented as a weighted sum of basis functions that are orthogonal to one another over the earth's surface. The surface source of a given member of this new suite of tracers is equal to the evaporation field multiplied by its associated basis function. The sources of water vapour are traced back through any cloud processes to the site of surface evaporation. The precipitation source distribution is a subset of the VSD, defined where vapour condenses to liquid.
This study uses spherical harmonics as VSD basis functions as these are not anchored to any particular geographic boundary and require no prior definition of regions. The "painted water" approach can be seen as a special case of the VSD tracers using binary basis functions at each gridbox. It should be noted that factors such as land-sea contrasts cause real-world precipitation source distributions to not vary smoothly over planetary scales. As such, the smooth shapes of VSDs cannot be interpreted literally. We include 144 tracers and resolve distributions to wavenumber 11, providing an effective horizontal resolution of vapour sources to approximately $8^{\circ} \times 10^{\circ}$.

VSD tracers cannot be employed in a comprehensively quantitative manner for tropical water isotopes, given that convection and mixing processes diminish the validity of a Lagrangian parcel-style approach to isotopic interpretation. Rather, the utility of the VSDs is as a vapour and precipitation weighted circulation diagnostic.

\subsection{Experiment design}

The VSD tracers utilised here are computationally expensive, slowing the model by a factor of 10 . Thus, we present water isotope results from the coupled model and VSD tracers from atmosphere-only model simulations driven by surface conditions (SST and sea ice) determined from the coupled simulation. A pre-industrial coupled, atmosphere-ocean VSD-enabled simulation was conducted to test the validity of atmosphere-only simulations, indicating only small differences in precipitation source distributions.

Hosing simulations were completed as part of the Paleoclimate Modelling Intercomparison Project (PMIP) experiment to test the sensitivity of the THC to an external source of freshwater (Stouffer et al., 2006). Although hosing experiments are highly idealised and not representative of a particular climatic event, they are useful in examining the response of tropical precipitation to abrupt cooling in the North Atlantic. Following the PMIP protocol (Stouffer et al., 2006), this study applies a freshwater flux $\left(\mathrm{T} 0{ }^{\circ} \mathrm{C} ; \mathrm{S} 0 \mathrm{psu}\right)$ of $1 \mathrm{~Sv}\left(1 \mathrm{~Sv}=10^{6} \mathrm{~m}^{3} / \mathrm{s}\right)$ uniformly over the Atlantic between $50^{\circ}$ and $70^{\circ} \mathrm{N}$ over 100 model years. Water isotopes are included in these experiments, and thus the freshwater has a specified depletion $\left(\delta^{18} \mathrm{O}-30 \%\right.$ ) consistent with observational estimates of the composition of ice discharge during $\mathrm{H}$ events (Hemming, 2004). A control (0 k) simulation, with no freshwater perturbation, was run in parallel with all boundary conditions and atmospheric composition appropriate to the pre-industrial period (ca. 1880).

Comparable control and hosing simulations were conducted in atmosphere-only mode with VSD tracers enabled. Initial conditions for the VSD-enabled hosing simulation were determined from anomalies calculated from the coupled simulations. Monthly SST and sea ice anomalies were defined as the difference of hosing model years 81 to 100 (where year 1 is the first hosing year) and pre-industrial 
Table 1. Summary of site types defined in terms of hydrological controls on $\delta^{18} \mathrm{O}_{p}$.

\begin{tabular}{ll}
\hline Type & Definition \\
\hline Type-1 & Local precipitation and $\delta^{18} \mathrm{O}_{p}$ changes consistent with local amount effect \\
Type-2 & Regional hydrological changes (monsoon intensity) upwind consistent with nonlocal $\delta^{18} \mathrm{O}_{p}$ amount effect \\
Type-3 & No amount effect operating, significant vapour source shifts dominate $\delta^{18} \mathrm{O}_{p}$ changes \\
Type-4 & Large shifts in the seasonality of precipitation produce corresponding annual $\delta^{18} \mathrm{O}_{p}$ changes \\
Type-5 & No explanation for isotopic signals in terms of precipitation, VSDs or seasonality changes \\
\hline
\end{tabular}

model years 41 to 140 . These date ranges coincide with anomalies reported in the PMIP study. Anomalies were applied to observed SST and sea ice fields as surface boundary conditions for the atmosphere-only simulation. The atmosphere only, VSD-enabled model was run for six years, with the final five years' results reported here.

\subsection{Definitions}

Model results are used to categorise tropical water isotopes sites in terms of regional hydrological and circulation changes. Specifically, we define five site types (Table 1) where,

1. Local precipitation and isotope changes are consistent with the amount effect, whereby $\delta^{18} \mathrm{O}_{p}$ is inversely correlated to local rainfall amount. Local precipitation changes are part of a coherent regional pattern and the site is reasonably distant from contours of zero precipitation changes.

2. Not all circumstances of Type-1 occur, but regional hydrological changes upwind are consistent with a nonlocal amount effect characterised by upwind prefractionation (i.e. upwind isotopic fractionation processes occurring prior to rain-out over specified region). In Type- 2 cases, local and upwind precipitation changes are not coherent. Hydrological changes are linked to monsoon intensity variability, as defined below.

3. No amount effect seems to be operating, but significant vapour source shifts can plausibly explain isotopic changes. Also, the source shift is consistent with expected circulation changes.

4. Shifts in the seasonality of precipitation produce corresponding changes in annual mean isotope signals. In this case, VSDs may be useful in explaining control isotopic seasonality due to the co-seasonality of isotopic changes and VSDs.

5. There is no explanation for isotope signals in terms of precipitation, VSDs or seasonality changes.

The classification of some sites is complex and most sites exhibit multiple $\delta^{18} \mathrm{O}_{p}$ controls and hence secondary effects are also identified. The categorisation of sites is suggested for hosing-driven $\delta^{18} \mathrm{O}_{p}$ changes only. As potentially different isotopic controls exist for climatic changes on different timescales (e.g. orbitally driven changes), generalisations of controls are not made.

As mentioned above, "monsoon" is often used to describe a variety of climatic phenomena. In order to examine regional hydrological changes, we define monsoon intensity using the zonal wind shear Webster-Yang (WY) index (Webster and Yang, 1992). The WY index is defined as the westerly wind shear anomaly between $850 \mathrm{hPa}$ and $200 \mathrm{hPa}$ pressure surfaces for June-August (JJA). The strength of the vertical shear is proportional to the strength of convective activity and associated latent heat released during the monsoon season as precipitation. During strong monsoon seasons, the upper air easterly and low-level westerly winds intensify. Conversely, during weak monsoon periods, zonal wind fields relax. This intensity definition from the Asian region is broadened to describe changes in monsoon strength over the South American monsoon area during the austral summer (DJF). We adopt the SM domain definition of Vuille and Werner (2005), which they identify as the centre of monsoonal convection in the region and consider dynamically consistent to the approach of Webster and Yang (1992). Dynamical monsoon indices have been employed previously as a measure of large-scale monsoon intensity changes and to characterise monsoon-isotope relationships (Brown, 2004; Vuille et al., 2005).

\section{Results}

The GISS ModelE-R simulation is part of the PMIP hosing experiment described by Stouffer et al. (2006). In general, mean GISS climatologies reside within the ensemble range of participating models. For all comparisons, climatic changes are reported as hosing anomalies relative to pre-industrial values. Specifically, anomalies are determined from mean values in control years 41 to 140 and hosing years 81 to 100 . All anomalies reported are greater than $95 \%$ significant given the control decadal variability about the 100 year mean. 


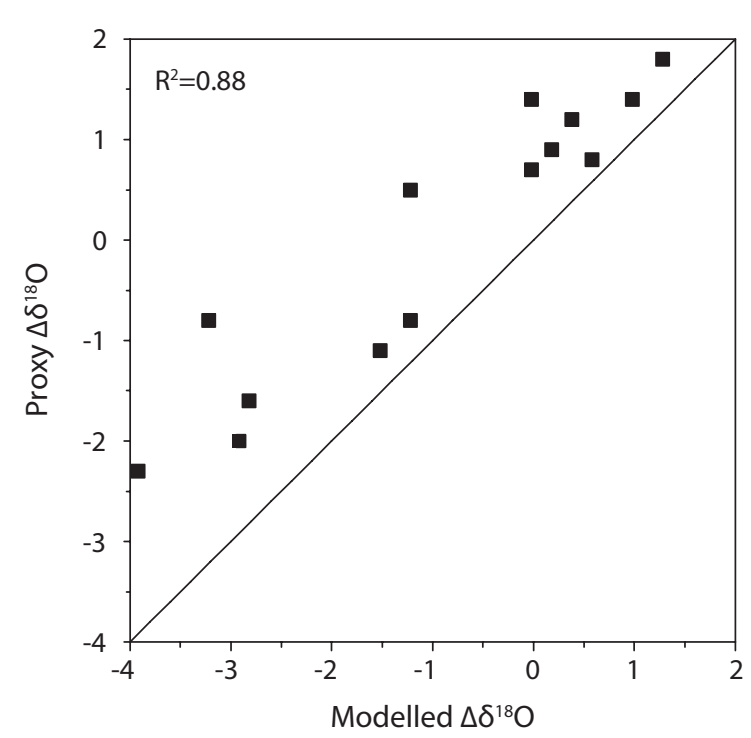

Fig. 2. Comparison of simulated average annual hosing $\Delta \delta^{18} \mathrm{O}$ and reconstructed Heinrich $\Delta \delta^{18} \mathrm{O}$ from selected proxy sites shown in Fig. $1\left(R^{2}=0.88\right)$. Reconstructed $\Delta \delta D$ from Lake Tanganyika (Tierney et al., 2008) is presented as a $\Delta \delta^{18} \mathrm{O}$ equivalent approximated using the Global Meteoric Water Line (Rozanski et al., 1993). The solid line indicates 1:1 relationship between modelled and observational values.

\subsection{Model $\delta^{18} \mathbf{O}_{p}$ validation}

Comparisons of simulated hosing-driven $\delta^{18} \mathrm{O}_{p}$ anomalies and measured $\delta^{18} \mathrm{O}$ records of $\mathrm{H}$ events are presented in Table 2 and Fig. 2. For consistency, $\delta^{18} \mathrm{O}_{p}$ excursions were averaged across all identifiable Heinrich events and estimated as the difference between average composition before an event and the extreme value during an event. Although North Atlantic oceanic sediment layers associated with $\mathrm{H} 3$ and $\mathrm{H} 6$ are considered geochemically unusual, with a contrasting provenance (Hemming, 2004), they are included here as their climatic expressions are comparable. In cases where values are reported from single gridboxes, these are coherent with changes over a broader area. Annual and seasonal $\delta^{18} \mathrm{O}$ hosing anomalies are shown in Fig. 3. The simulated hosing $\Delta \delta^{18} \mathrm{O}$ spatial pattern is broadly consistent with proxy records (Fig. 2).

In the high latitudes, we simulate depleted precipitation (ANN $\Delta \delta^{18} \mathrm{O}_{p}-3.9 \%$; JJA $\Delta \delta^{18} \mathrm{O}_{p}-2.8 \%$; DJF $\Delta \delta^{18} \mathrm{O}_{p}$ $-9.2 \%$ o) over Greenland, consistent with $\mathrm{H}$ events documented in the GRIP record $\left(\Delta \delta^{18} \mathrm{O}-2.3 \%\right.$; Bond et al., 1993; GRIP Members, 1993). The addition of highly isotopically depleted freshwater to the region and associated changes in the isotopic composition of surface seawater $\left(\delta^{18} \mathrm{O}_{\mathrm{sw}}\right)$ contribute to comparatively light regional $\delta^{18} \mathrm{O}_{p}$. Further decreases in $\delta^{18} \mathrm{O}_{\mathrm{sw}}$ result from the reductions in northward transport of tropical surface water into the region (Fig. 3). Isotopic enrichments over Antarctica are an or- der of magnitude lower than those in the high-latitudes of the Northern Hemisphere (NH). In the Southern Hemisphere (SH) high-latitudes, there are minimal hosing-driven $\delta^{18} \mathrm{O}_{p}$ changes. At Byrd ice core site, no statistically significant annual average $\delta^{18} \mathrm{O}_{p}$ change is simulated, compared to the $\sim 0.7 \%$ o reconstructed Heinrich shift (Blunier et al., 1998). Conversely, over Taylor Dome, the modelled $\delta^{18} \mathrm{O}_{p}$ change is a $-0.6 \%$ depletion, which is similar to the $\sim-1.2 \%$ o $\delta^{18} \mathrm{O}$ shift estimated from proxy data covering $\mathrm{H}$ events (Grootes et al., 2001).

In the mid-latitudes, European speleothems covering marine isotope stage 3 are sparse and existing records are typically limited by low calcite growth rates. At Poleva cave in Romania $\left(44^{\circ} 4^{\prime} \mathrm{N}, 21^{\circ} 5^{\prime} \mathrm{E}\right)$, a $\delta^{18} \mathrm{O}$ excursion $(\sim-2.0 \%$ o recorded around $\mathrm{H} 4$ is similar to the simulated hosing change (ANN $\Delta \delta^{18} \mathrm{O}_{p}-2.9 \%$ ), although this stadial is constrained by only four geochemical data points over $\sim 5 \mathrm{kyr}$ (Constantin et al., 2007).

Across the tropics, a broadly anti-phased $\delta^{18} \mathrm{O}_{p}$ pattern is modelled across the hemispheres. Depleted $\delta^{18} \mathrm{O}_{p}$ values are simulated across the tropical southern Pacific, Atlantic and Indian Oceans, the West Pacific Warm Pool, eastern South America and southern Africa. Conversely, enriched values are modelled over most of southern Asia and central Africa, corresponding to increased precipitation associated with the southward migration of the ITCZ. Proxy records from the East Asian and Indian monsoon domains consistently exhibit enriched $\delta^{18} \mathrm{O}_{\text {calcite }}$ values during $\mathrm{H}$ events and generally enriched precipitation is modelled over China (ANN $\Delta \delta^{18} \mathrm{O}_{p}$ $0.6 \%$ o) and India (ANN $\Delta \delta^{18} \mathrm{O}_{p} 1.4 \%$ ). Simulated hosing $\delta^{18} \mathrm{O}_{p}$ enrichment is largest during the boreal summer (China JJA $\Delta \delta^{18} \mathrm{O}_{p} 0.6 \%$; India JJA $\Delta \delta^{18} \mathrm{O}_{p} 2.4 \%$ ). Anomalies in this region are spatially complex with a seasonally robust hosing zero $\Delta \delta^{18} \mathrm{O}_{p}$ front transecting China, with positive anomalies to the south and negative to the north. The correspondence of modelled and reconstructed $\delta^{18} \mathrm{O}$ anomalies is variable. Excursions in simulated $\delta^{18} \mathrm{O}_{p}$ are consistent with reconstructed values at Songjia cave (Zhou et al., 2008), although modelled $\delta^{18} \mathrm{O}$ enrichments are lower than proxy excursions at Sanbao $\left(31^{\circ} 4^{\prime} \mathrm{N}, 110^{\circ} 3^{\prime} \mathrm{E}\right.$; Wang et al., 2008) and Moomi cave in Yemen $\left(31^{\circ} 4^{\prime} \mathrm{N}, 110^{\circ} 3^{\prime} \mathrm{E}\right.$; Shakun et al., 2007).

Over Brazil, modelled isotopically depleted precipitation (ANN $\Delta \delta^{18} \mathrm{O}_{p}-2.7 \%$; JJA $\Delta \delta^{18} \mathrm{O}_{p}-1.7 \%$; DJF $\Delta \delta^{18} \mathrm{O}_{p}$ $-3.1 \%$ o) is consistent with $\mathrm{H}$ event reconstructions. At Rio Grande do Norte $\left(31^{\circ} 4^{\prime} \mathrm{N}, 110^{\circ} 3^{\prime} \mathrm{E}\right.$; Cruz et al., 2009) and Santana $\left(31^{\circ} 4^{\prime} \mathrm{N}, 110^{\circ} 3^{\prime} \mathrm{E}\right.$; Cruz et al., 2006b) caves, simulated annual $\Delta \delta^{18} \mathrm{O}_{p}$ is greater than the reconstructed average $\delta^{18} \mathrm{O}$ change over $\mathrm{H}$ events. This discrepancy in $\Delta \delta^{18} \mathrm{O}$ magnitude may relate to the method of averaging proxy excursions, which excluded extreme $\delta^{18} \mathrm{O}_{\text {calcite }}$ values represented by a single data point. Further agreement between reconstructed and modelled isotopic values occurs over Borneo $\left(4^{\circ} \mathrm{N}, 114^{\circ} \mathrm{E}\right.$; Partin et al., 2007) and at Lake Tanganyika, Africa $\left(6^{\circ} 4^{\prime} \mathrm{S}, 29^{\circ} 5^{\prime} \mathrm{E}\right.$; Tierney et al., 2008). 
Table 2. Comparisons of isotopic proxy records with annual average modelled $\delta^{18} \mathrm{O}_{p}$ and precipitation hosing anomalies at relevant gridboxes. Proxy data excursions are estimated from average baseline $\delta^{18} \mathrm{O}$ values prior to the timing of a Heinrich event and averaged across all identifiable excursions.

\begin{tabular}{|c|c|c|c|c|}
\hline \multirow[b]{2}{*}{ Location } & \multirow[b]{2}{*}{ Site lat,long } & \multirow[b]{2}{*}{$\begin{array}{r}\text { Data } \Delta \delta^{18} \mathrm{O} \\
(\% o)\end{array}$} & \multicolumn{2}{|c|}{ Modelled annual $\Delta$ Hosing } \\
\hline & & & $\begin{array}{r}\delta^{18} \mathrm{O} \\
(\% \circ)\end{array}$ & $\begin{array}{r}\text { PRECIP } \\
(\mathrm{mm} / \text { day })\end{array}$ \\
\hline GRIP & $72^{\circ} \mathrm{N}, 37^{\circ} \mathrm{W}$ & -2.3 & -3.9 & -0.1 \\
\hline Byrd & $80^{\circ} 0^{\prime} \mathrm{S}, 119^{\circ} 3^{\prime} \mathrm{W}$ & 0.7 & 0.0 & 0.1 \\
\hline Taylor Dome & $77^{\circ} 5^{\prime} \mathrm{S}, 158^{\circ} 4^{\prime} \mathrm{E}$ & -1.2 & -0.6 & 0.1 \\
\hline Hulu cave & $32^{\circ} 3^{\prime} \mathrm{N}, 119^{\circ} 1^{\prime} \mathrm{E}$ & 1.4 & 0.0 & 0.2 \\
\hline Songjia cave & $32^{\circ} 2^{\prime} \mathrm{N}, 107^{\circ} 1^{\prime} \mathrm{E}$ & 1.4 & 1.0 & -1.0 \\
\hline Sanbao cave & $31^{\circ} 4^{\prime} \mathrm{N}, 110^{\circ} 3^{\prime} \mathrm{E}$ & 1.2 & 0.4 & 0.6 \\
\hline Borneo & $4^{\circ} \mathrm{N}, 114^{\circ} \mathrm{E}$ & 0.8 & 0.6 & -0.5 \\
\hline Liang Luar cave & $8^{\circ} 3^{\prime} \mathrm{S}, 120^{\circ} 3^{\prime} \mathrm{E}$ & Hiatus & -0.7 & 0.8 \\
\hline Moomi cave & $12^{\circ} 3^{\prime} \mathrm{N}, 54^{\circ} 2^{\prime} \mathrm{E}$ & 0.9 & 0.2 & -0.1 \\
\hline Soreq & $31^{\circ} 3^{\prime} \mathrm{N}, 35^{\circ} 0^{\prime} \mathrm{E}$ & 0.5 & -1.2 & 0.0 \\
\hline Lake Tanganyika & $6^{\circ} 4^{\prime} \mathrm{S}, 29^{\circ} 5^{\prime} \mathrm{E}$ & $14.5(\delta D)$ & $1.3,11.9(\delta D)$ & 0.0 \\
\hline Rio Grande do Norte & $5^{\circ} 4^{\prime} \mathrm{S}, 37^{\circ} 4^{\prime} \mathrm{W}$ & -1.6 & -2.8 & 1.2 \\
\hline Toca da Boa Vista & $10^{\circ} 1^{\prime} \mathrm{S}, 40^{\circ} 5^{\prime} \mathrm{W}$ & Growth periods & -3.5 & 2.4 \\
\hline Santana cave & $24^{\circ} 3 / \mathrm{S}, 48^{\circ} 4 / \mathrm{W}$ & -0.8 & -3.2 & 0.3 \\
\hline Botuverá cave & $27^{\circ} 1^{\prime} \mathrm{S}, 49^{\circ} 1^{\prime} \mathrm{W}$ & -1.1 & -1.5 & 0.1 \\
\hline Cave of the Bells & $31^{\circ} 4^{\prime} \mathrm{N}, 110^{\circ} 5^{\prime} \mathrm{W}$ & -0.8 & -1.2 & 0.4 \\
\hline Poleva cave & $44^{\circ} 4^{\prime} \mathrm{N}, 21^{\circ} 5^{\prime} \mathrm{E}$ & -2.0 & -2.9 & -0.4 \\
\hline China region & $26-34^{\circ} \mathrm{N}, 105-120^{\circ} \mathrm{E}$ & 1.3 & 0.6 & 0.2 \\
\hline Brazil region & $4-30^{\circ} \mathrm{S}, 40-50^{\circ} \mathrm{W}$ & -1.2 & -2.9 & 1.1 \\
\hline
\end{tabular}

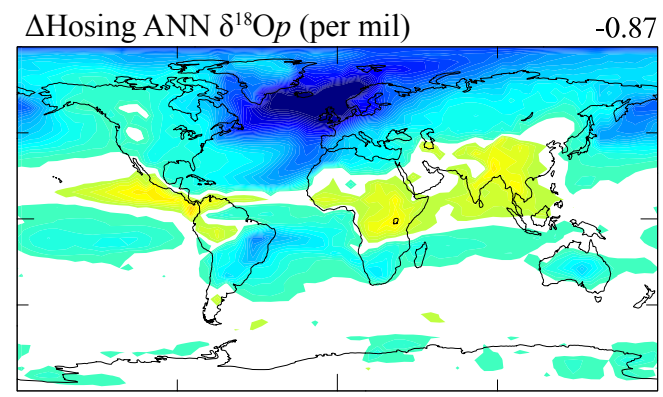

$\Delta$ Hosing ANN $\delta^{18} \mathrm{O} s w($ per mil)

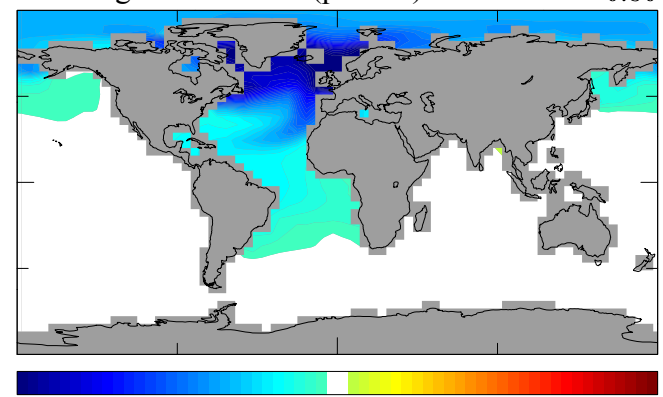

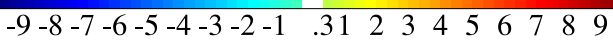
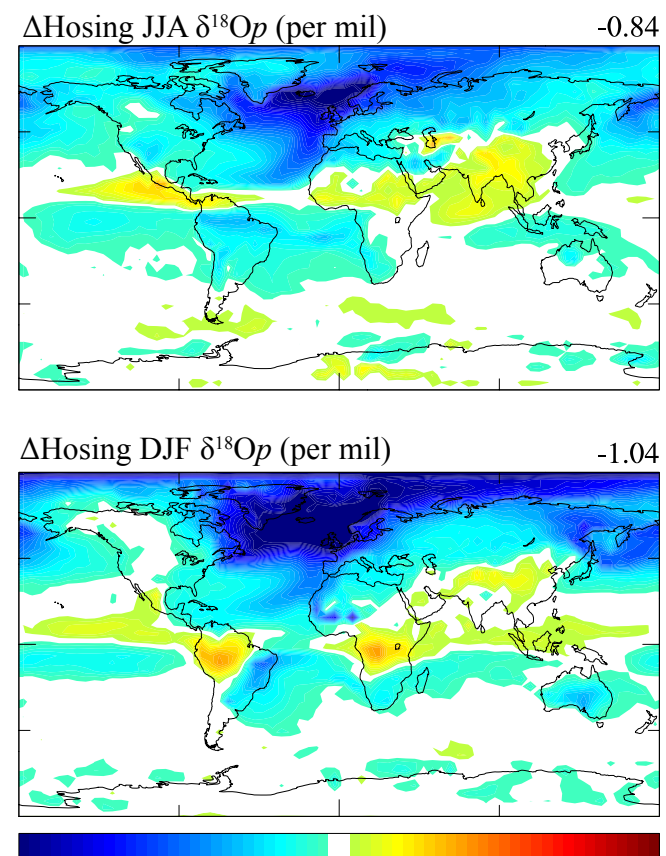

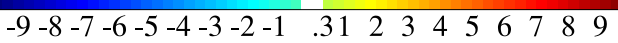

Fig. 3. Annual average hosing $\delta^{18} \mathrm{O}_{p}$ and $\delta^{18} \mathrm{O}_{\text {sw }}$ changes and seasonal $\delta^{18} \mathrm{O}_{p}$ anomalies for boreal summer (JJA) and winter (DJF). All values reported are greater than $95 \%$ significant (student's t-test) given the decadal variability about the 100-year mean. Global mean anomalies are given at the top right of each panel. 

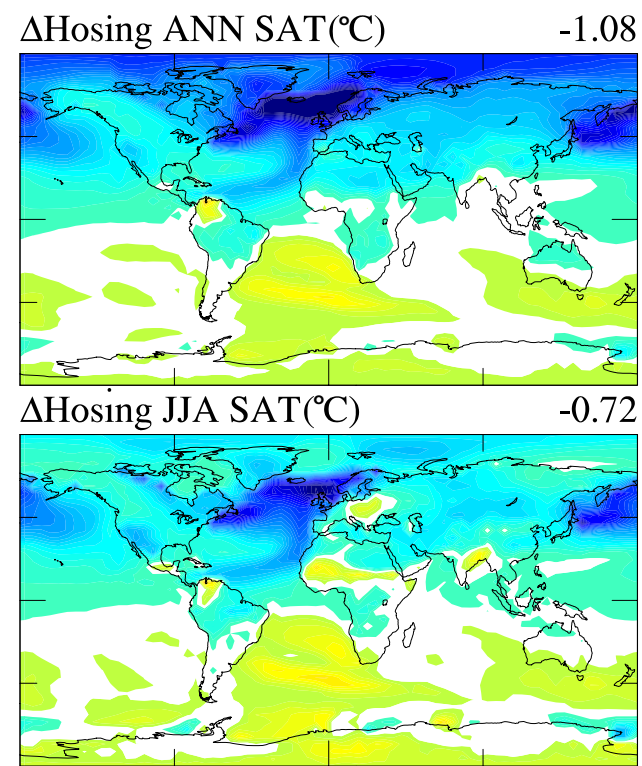

$-0.72$
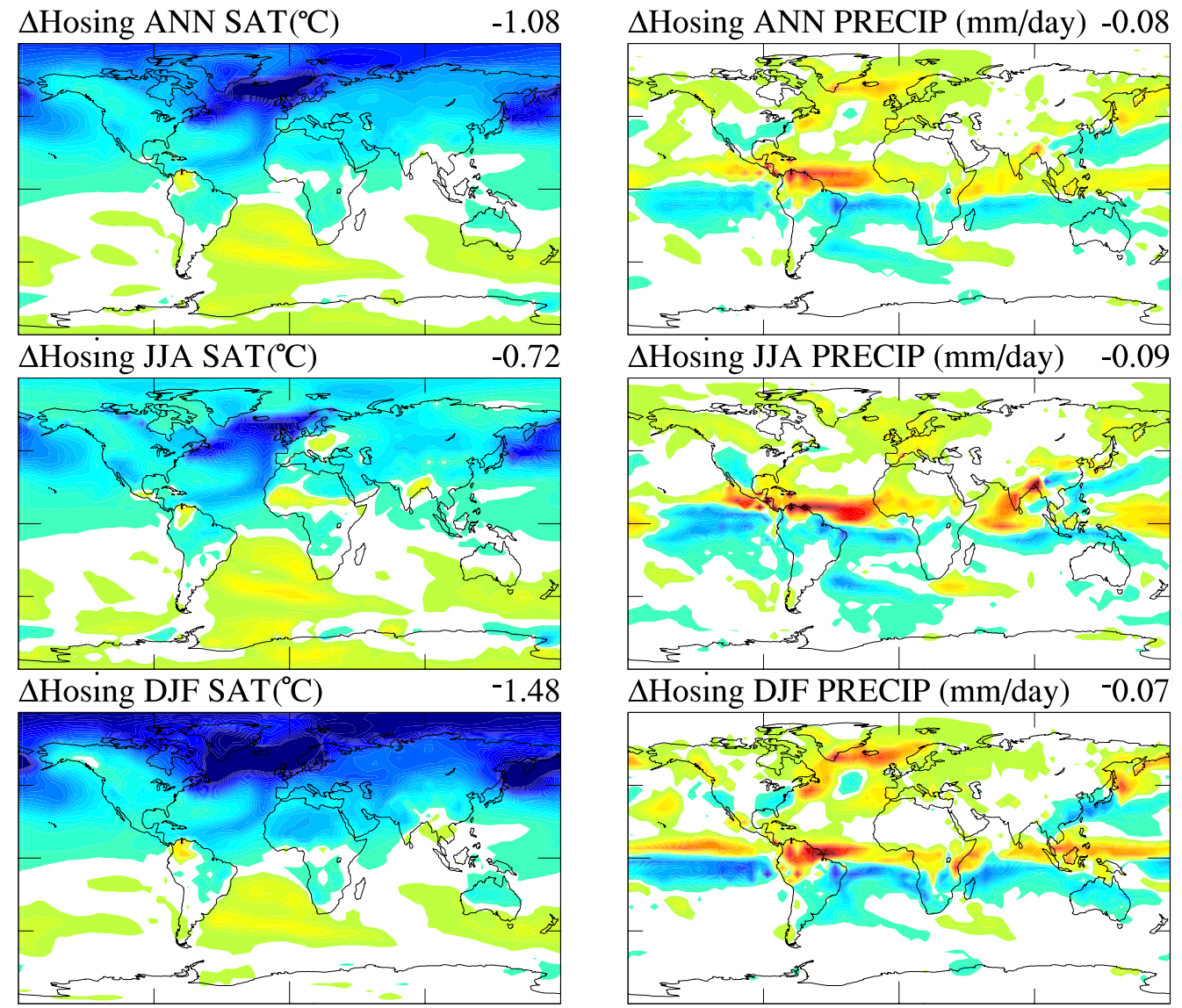

$-9-8-7-6-5-4-3-2-1 \quad .31 .73456789$

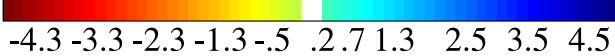

Fig. 4. Annual and seasonal (JJA and DJF) average hosing anomalies for SAT ( ${ }^{\circ} \mathrm{C}$, left) and precipitation (mm/day, right). All values reported are greater than $95 \%$ significant (student's t-test) given the decadal variability about the 100-year mean. Global mean anomalies are given at the top right of each panel.

There are also simulated isotopic shifts that do not directly compare with proxy records. At Hulu cave $\left(32^{\circ} 3^{\prime} \mathrm{N}\right.$, $119^{\circ} 1^{\prime} \mathrm{E}$ ), modelled $\delta^{18} \mathrm{O}_{p}$ shows no significant hosing change compared to a $\sim 1.4 \%$ o reconstructed enrichment (Wang et al., 2001). Here, modelled modern $\delta^{18} \mathrm{O}_{p}$ and precipitation are similar to Global Network of Isotopes in Precipitation (GNIP; IAEA/WMO, 2006; Bowen, 2009) and Climate Prediction Centre Merged Analysis of Precipitation data (CMAP; Xie and Arkin, 1996). Hulu lies close to the zero $\delta^{18} \mathrm{O}_{p}$ anomaly line and the coarse model resolution utilised may be inadequate.

In southwestern USA at Cave of Bells $\left(31^{\circ} 4^{\prime} \mathrm{N}, 110^{\circ} 3^{\prime} \mathrm{E}\right.$; Wagner et al., 2010), the reconstructed $\left(\Delta \delta^{18} \mathrm{O}_{\text {calcite }}-0.8 \%\right.$ ) and simulated (ANN $\Delta \delta^{18} \mathrm{O}_{p}-1.2 \%$; JJA $\Delta \delta^{18} \mathrm{O}_{p}$; $-2.5 \%$; DJF $\Delta \delta^{18} \mathrm{O}_{p} 0 \%$ o) excursion is comparable. However, contemporary monitoring indicates calcite precipitates only during the winter months (DJF) due to high summer evaporation and runoff. Modelled winter precipitation anomalies indicate insignificant $\delta^{18} \mathrm{O}_{p}$ changes, in contrast with re- constructed values. This discrepancy may indicate that the large-scale changes in hydrology occurring during abrupt changes may allow a calcite deposition regime to transpire that is significantly different from the modern. In this case, a comparison of annual average hosing values with modern winter average may be more valid, although this indicates a $\Delta \delta^{18} \mathrm{O}_{p}$ enrichment of $\sim 0.8 \%$ o. Alternatively, this discrepancy may result from model inadequacies around this comparatively high altitude site (1700 m a.s.l.) or a seasonal bias in modelled precipitation fields.

At Soreq cave $\left(31^{\circ} 3^{\prime} \mathrm{N}, 35^{\circ} \mathrm{E}\right)$, reconstructed Heinrich $\Delta \delta^{18} \mathrm{O}_{\text {calcite }}$ values indicate a $0.5 \%$ enrichment, while modelled $\delta^{18} \mathrm{O}_{p}$ values record a $1.2 \%$ o depletion (Bar-Matthews et al., 1999). Modelled modern precipitation values at Soreq are similar to CMAP data, although $\delta^{18} \mathrm{O}_{p}$ is relatively enriched $(\sim 2 \%$ ) compared to GNIP and dripwater observations (Matthews et al., 2000). The relative enrichment of modelled precipitation to observed is likely because the model does not adequately resolve the Strait of Gibraltar, resulting in 

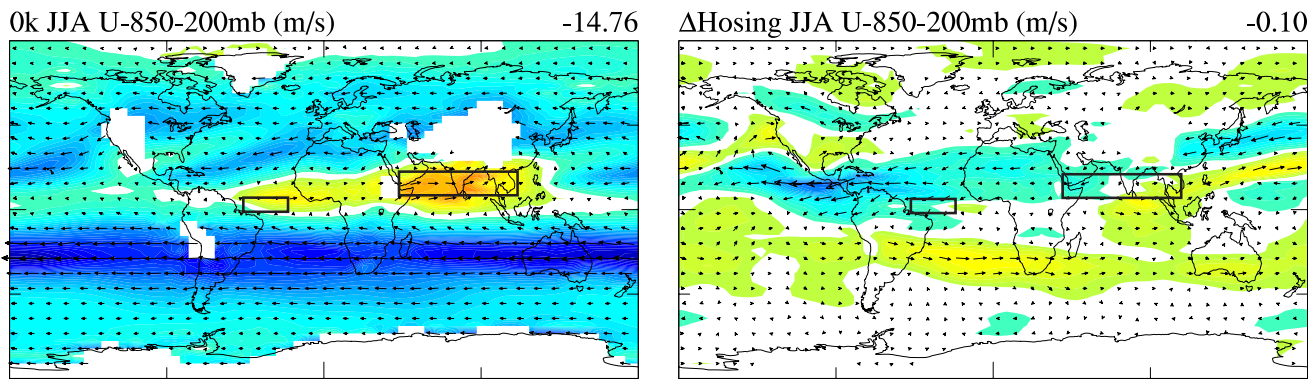

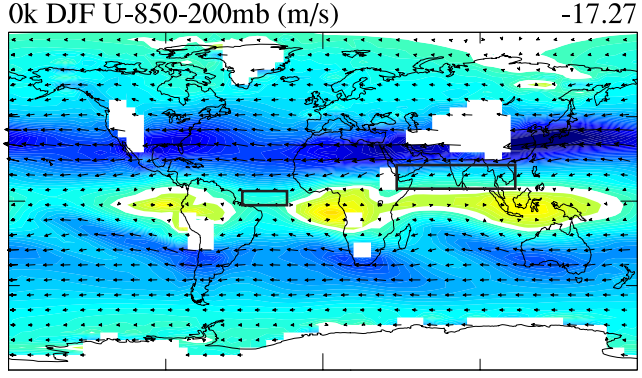

$-54-46-38-30-22-14-6 \quad 261218243036424854$

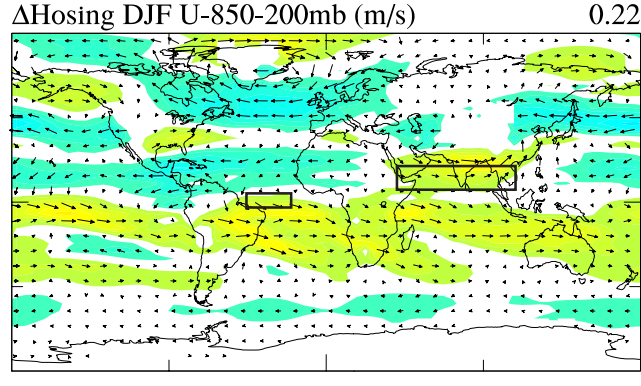

$-27-23-19-15-11-7-4-113579121518212427$

Fig. 5. Modelled 850-200 mb zonal winds (m/s, WY monsoon intensity index) for JJA (top) and DJF (bottom) seasons for control run (left) and hosing anomalies (right). Rectangular boxes indicate Asian $\left(5^{\circ}-20^{\circ} \mathrm{N}, 40^{\circ}-110^{\circ} \mathrm{E}\right)$ and South American $\left(2.5^{\circ} \mathrm{S}-7.5^{\circ} \mathrm{N}, 20-45^{\circ} \mathrm{W}\right)$ monsoon region (defined by Vuille and Werner, 2005). Solid white shading indicates areas of high model topography. Global mean values are given at the top right of each panel.

enriched $\delta^{18} \mathrm{O}_{\text {sw }}$ composition $(\sim 2 \%$ ) in the Mediterranean compared with observed values $(\sim 1.3-1.7 \%$; Gat, 1996; Paul et al., 2001). Rainfall over Soreq is dominated by Mediterranean storm fronts (Bar-Matthews et al., 1996) and modelled rainfall is susceptible to bias in Mediterranean $\delta^{18} \mathrm{O}_{\text {sw }}$. As simulated hosing $\delta^{18} \mathrm{O}_{p}$ changes contradict reconstructed isotopic values from Soreq cave and Cave of Bells speleothems, classification of the dominant control of simulated $\delta^{18} \mathrm{O}_{p}$ at these sites is not attempted.

\subsection{Large-scale climate changes}

There are significant simulated global climatic changes following North Atlantic freshwater injection. The mean control NADW formation (Atlantic overturning streamfunction at $48^{\circ} \mathrm{N}$ and $900 \mathrm{~m}$ depth) is $13 \mathrm{~Sv}$ and the long-term mean simulated THC intensity and decadal-scale variability are within the PMIP ensemble range of 12-25 Sv (Stouffer et al., 2006). In this study, THC collapse occurs after $\sim 50$ years and intensity increases steadily after the forcing is eliminated.

Diminished NADW decreases SSTs and is associated with significant global SAT changes $\left(\mathrm{ANN}-1.1^{\circ} \mathrm{C}\right.$; JJA $-0.7^{\circ} \mathrm{C}$; DJF $-1.5^{\circ} \mathrm{C}$, Fig. 4), near the ensemble mean annual cooling of $\sim 1^{\circ} \mathrm{C}$ (Stouffer et al., 2006). The most significant cooling $\left(\mathrm{ANN}-8.9^{\circ} \mathrm{C}\right.$ ) occurs over the North Atlantic, with the entire Northern Hemisphere cooling annually by $\sim 2.4^{\circ} \mathrm{C}$; a small annual warming occurs over the Antarctic (ANN $0.2^{\circ} \mathrm{C}$; JJA $0.3^{\circ} \mathrm{C}$; DJF $0{ }^{\circ} \mathrm{C}$ ). Southern Hemisphere warming (ANN $0.2^{\circ} \mathrm{C}$ ) is an expression of the bipolar seesaw (Broecker, 1998).

Sea surface temperature anomalies broadly match ensemble results, with a modelled annual average global cooling of $0.4{ }^{\circ} \mathrm{C}$. It should be noted that many participating PMIP models utilise a "rigid lid" ocean (which "add" freshwater via equivalent salt fluxes), whereas the GISS model incorporates a free surface, where added freshwater has the physical property of $0^{\circ} \mathrm{C}$, limiting the non-physical distortion of the coupling over the gridboxes where freshwater is added. Sea ice extent increases following the NADW shutdown, and the majority of the North Atlantic north of $50^{\circ} \mathrm{N}$ is ice-covered in wintertime.

The simulated perturbation of the SST gradient across the hemispheres following hosing results in a southward shift in the ITCZ by $1-2$ gridboxes ( $\sim-8^{\circ}$ in latitude, Fig. 4$)$. There is a global annual average $0.1 \mathrm{~mm}$ /day decrease in precipitation, characterised by an increase in the southern tropics (ANN $0.2 \mathrm{~mm} /$ day) and a decrease in the northern tropics (ANN $-0.4 \mathrm{~mm} /$ day). Precipitation anomalies are seasonally variable. The strongest precipitation decreases around the North Atlantic occur during the winter months (DJF $-1.1 \mathrm{~mm} /$ day), whilst through the tropics and particularly over Asia, larger precipitation changes occur during the boreal summer. 

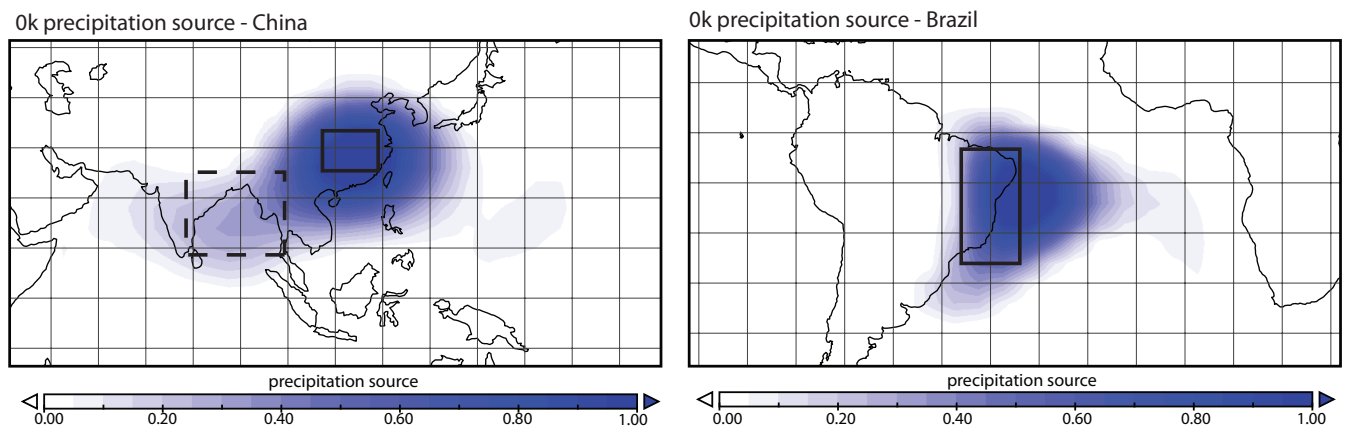

$\Delta$ Hosing precipitation source change - China

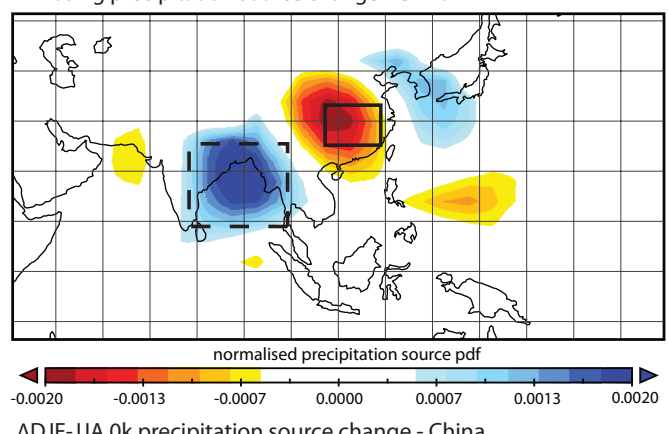

$\Delta$ Hosing precipitation source change - Brazil

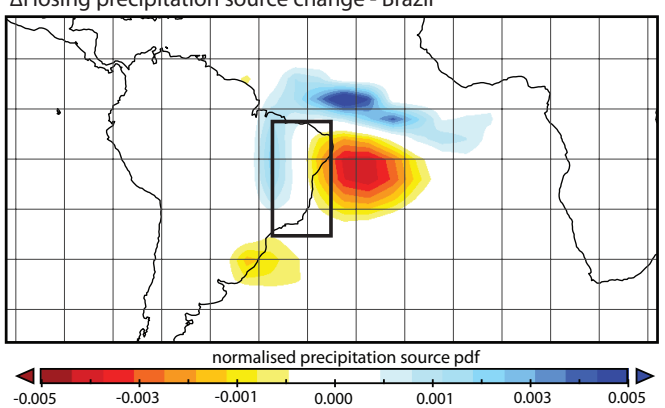

$\triangle$ DJF-JJA Ok precipitation source change - China

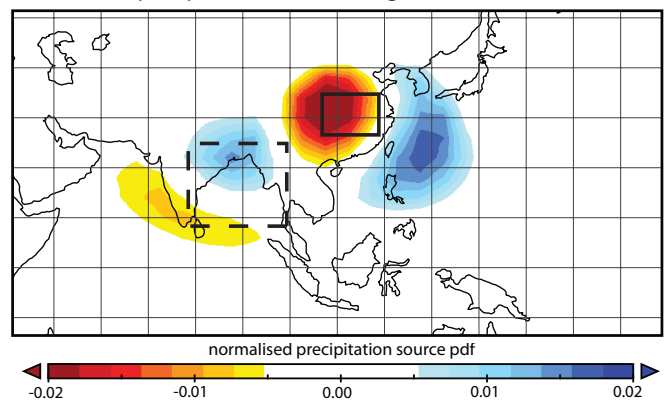

$\triangle J$ JA-DJF 0k precipitation source change - Brazil

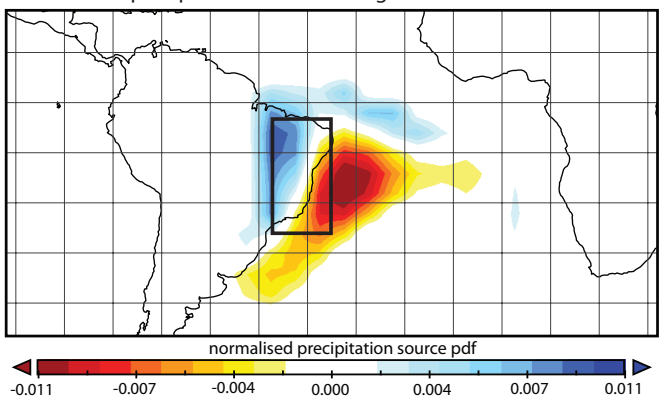

Fig. 6. Control precipitation source distributions ( $\mathrm{Ok})$, and hosing and modern seasonal precipitation source region anomalies for China $\left(26-34^{\circ} \mathrm{N}, 105-120^{\circ} \mathrm{E}, \mathrm{DJF}-\mathrm{JJA}\right)$ and Brazil (4-30 $\left.\mathrm{S}, 40-50^{\circ} \mathrm{W}, \mathrm{JJA}-\mathrm{DJF}\right)$. Solid rectangular boxes indicate the location of end member precipitation and dashed boxes indicate Bay of Bengal source region to China. Note that seasonal and hosing anomalies are plotted on different scales. VSDs are unitless probability density functions, normalised by the maximum probability density.

There are significant hosing-driven changes in modelled oceanic and atmospheric heat transport that impact water vapour transport and the distribution of heavy isotopes in precipitation. The maximum simulated northward heat transport in the Atlantic Ocean is $0.82 \mathrm{PW}$ ( 1 PetaWatt $=10^{15}$ Watts), within the multi-model ensemble range of $0.7-1.1 \mathrm{PW}$ (Stouffer et al., 2006). There is a decrease in northward heat transport in the Atlantic following freshwater perturbation to $0.16 \mathrm{PW}$ at $20^{\circ} \mathrm{N}$ (near the ensemble mean of $0.13 \mathrm{PW}$ ), and an overall reduction in total oceanic heat transport during the hosing simulation. Total northward atmospheric heat transport, integrated throughout the atmosphere, generally increases in the hosing simulation from the SH tropics through to the northern mid-latitudes. Hosing-driven increases in atmospheric heat transport do not entirely account for the decrease in northward oceanic heat transport, with a $\sim 0.3 \mathrm{PW}$ deficit simulated.
Using the WY index (Webster and Yang, 1992) to define monsoon intensity, the simulated seasonal zonal wind shear indicates a freshwater-forced increase in convergence and monsoon intensification over the South American region (Fig. 5). Conversely, only a small hosing-driven decrease in zonal flow (monsoon intensity) in the Asian monsoon domain in modelled. Also, significant freshwater-forced changes in the amount of water vapour transported landward from oceanic source are simulated, due to changes in both atmospheric wind profiles and humidity. Generally, there is a decrease in transport of water vapour westward into East Asia under weakened monsoon circulation. Reductions in landward water vapour fluxes are strongest in the boreal summer, with a large reduction in meridional transport from the tropical west Pacific. Conversely, increases in the landward transport of water vapour from the tropical Atlantic over equatorial South America occur during hosing simulations. 


\subsection{Precipitation amount and seasonality changes}

Over China (shown in Fig. 6), we simulate an overall increase in precipitation (ANN $0.2 \mathrm{~mm} /$ day; JJA $0.1 \mathrm{~mm} /$ day; DJF $0.9 \mathrm{~mm} /$ day). There is a distinct seasonality of control precipitation over the EAM region (defined by $\mathrm{Li}$ and Zeng (2002), with $\sim 45 \%$ of precipitation occurring during the summer months (JJA) and 5\% during winter, with an average seasonal isotopic difference of $\sim-4.3 \%$. However, Chinese speleothem sites occur largely outside the peak area of EAM rainfall and experience a subdued seasonality, with $\sim 26 \%$ occurring during summer (JJA) and $\sim 15 \%$ during winter (DJF). There are minimal simulated seasonality changes of $\sim 4 \%$ increase in Chinese winter rainfall to the annual total. The greatest hosing-driven change in precipitation seasonality occurs at Songjia cave, where there is an overall decrease in precipitation (ANN $-1.0 \mathrm{~mm} /$ day; JJA $-1.2 \mathrm{~mm} /$ day; DJF $0.3 \mathrm{~mm} /$ day). At Sanbao cave, simulated increases in local precipitation (ANN $0.6 \mathrm{~mm} /$ day; JJA 0.7 $\mathrm{mm} /$ day; DJF $1.1 \mathrm{~mm} /$ day) result in an increase in the relative contribution of winter rainfall to the annual total. Over Hulu cave, where no significant annual precipitation amount change is modelled, there is an increase in the relative contribution of winter precipitation to the annual total, consistent with coastal sedimentary records (Yancheva et al., 2007).

Throughout the Brazil region (Fig. 6), there is a seasonally robust hosing-driven increase in simulated precipitation (ANN $1.1 \mathrm{~mm} /$ day; JJA $0.7 \mathrm{~mm} /$ day; DJF $1.3 \mathrm{~mm} /$ day). There is also a decrease (by $22 \%$ ) in the proportion of winter (JJA) rainfall from $\sim 33 \%$ of the annual simulated control total. Generally, the seasonality of precipitation is greater over Brazil following hosing. The decrease in the contribution of hosing winter precipitation, which is enriched relative to summer precipitation $\left(\Delta \delta^{18} \mathrm{O}_{p} \sim 5.3 \%\right.$ ) , is also associated with depleted $\delta^{18} \mathrm{O}_{p}$ (ANN $\Delta \delta^{18} \mathrm{O}_{p}-2.7 \%$; JJA $\Delta \delta^{18} \mathrm{O}_{p}$ $-1.7 \%$; DJF $\Delta \delta^{18} \mathrm{O}_{p}-3.1 \%$ ).

Around the Warm Pool, there is an annual average decrease in precipitation modelled over Borneo (ANN $-0.5 \mathrm{~mm} /$ day; JJA $0.9 \mathrm{~mm} /$ day; DJF $-2.4 \mathrm{~mm} /$ day). Further south at Liang Luar cave, southern Indonesia, hosing simulations indicate robust year-round precipitation increases (ANN $0.8 \mathrm{~mm} /$ day; JJA $0.8 \mathrm{~mm} /$ day; DJF $0.6 \mathrm{~mm} /$ day). The seasonality of precipitation over Borneo is weak, with warm SSTs driving year-round atmospheric deep convection (Cobb et al., 2007). At both sites, there is a decrease in the seasonality of precipitation after freshwater perturbation. For example, over Borneo $\sim 19 \%$ of simulated control rainfall occurs during JJA ( $\triangle$ Hosing $\sim 4 \%$ ) and $\sim 37 \%$ throughout DJF ( $\Delta$ Hosing $\sim-6 \%)$.

At Lake Tanganyika, seasonally variable hosing-driven precipitation changes (ANN $0 \mathrm{~mm} /$ day; JJA $0.1 \mathrm{~mm} /$ day; DJF $-0.9 \mathrm{~mm} /$ day) are simulated. Although no statistically significant annual average precipitation amount changes are modelled, regional SH increases associated with the ITCZ shift are simulated. The seasonality of precipitation is si- milar in both control and hosing simulations. Over Moomi cave, Yemen, year-round decreases in hosing precipitation are simulated (ANN $-0.1 \mathrm{~mm} /$ day; JJA $-0.2 \mathrm{~mm} /$ day; DJF $-0.1 \mathrm{~mm} /$ day), together with a slight decrease in the contribution of winter (JJA) rainfall to the annual total by $\sim 5 \%$.

\subsection{Vapour source distributions}

For proxy locations detailed in Fig. 1, we identify hosing precipitation source region changes (Table 3). We define recycled water as water with a continental, rather than oceanic source. It should be noted that GCMs can overestimate the extent of regional recycling in the hydrological cycle, relative to advective moisture sources (Ruiz-Barradas and Nigam, 2006). Mean water vapour transport distances (TD) are calculated as the distance between the mean location of the precipitation source distribution and the proxy site. This provides a lower estimate of overall air mass TD as curved parcel trajectories cannot be accounted for. The initial source $\delta^{18} \mathrm{O}$ composition $\left(\delta^{18} \mathrm{O}_{\text {source }}\right)$ is calculated as the average surface $\delta^{18} \mathrm{O}$ within the simulated source region, including both land and ocean gridboxes.

Over China, modelled annual control precipitation consists of $\sim 50 \%$ recycled water vapour from continental Asia. Approximately $25 \%$ of rainfall is sourced from the northwest Pacific and continental Asia, 40\% from the Warm Pool region and southern continental China and $\sim 20 \%$ from the Bay of Bengal (Fig. 6). Compared with winter (DJF), during the summer months (JJA) there is an increase in the transport of vapour from the Indian Ocean $(\sim 27 \%)$ and decrease in Pacific-sourced precipitation $(\sim 25 \%)$. Mean modelled precipitation source pathways to China are $380 \mathrm{~km}$ more local during winter than summer. Overall, modelled sources are consistent with observations indicating that winter precipitation is sourced under different conditions from summer rainfall, with a change to more local western Pacific sources (Araguás-Araguás et al., 1998). The pattern of hosing-driven source region changes to China is dominated by an increase in precipitation with a provenance in the Bay of Bengal (shown in Fig. 6). It should be noted, however, that the seasonal cycle in the control simulation does not clearly represent an analogue for hosing-driven changes over this region, as the changes associated with hosing are an order of magnitude smaller than those occurring between the seasons, particularly over the East China Sea.

Hosing source region changes are also simulated over areas of eastern Brazil (Fig. 6). Here, 22\% of modelled precipitation is locally recycled, with the bulk of precipitation sourced from the Atlantic Ocean and minimal long distance transport of vapour. Compared with winter (JJA), during the summer months (DJF) there is a greater proportion of precipitation recycling (26\%), a northward shift in the mean source location and the mean transport distance of water vapour is $\sim 260 \mathrm{~km}$ greater. The modelled source pattern is consistent with observed modern rainfall observations indicating 
that winter rainfall incorporates a larger fraction of Atlantic Ocean derived moisture than summer (DJF) rainfall, which is associated with enhanced convective activity over the Amazon (Cruz et al., 2006a). The spatial pattern of mean annual VSD hosing anomalies is similar to the simulated seasonal source shift of the seasonal cycle in the control simulation. Both instances involve a southward ITCZ migration, although the magnitude of seasonal source anomalies changes is greater by a factor of $\sim 2$ than those simulated following freshwater injection.

Significant hosing-driven source region changes to individual tropical sites are also simulated (Fig. 7), largely due to freshwater-forced alterations in SSTs and resulting shifts in the mean ITCZ location. Over Borneo, there is a small hosing-driven reduction in modelled precipitation transported from the Pacific. This is accompanied by an increase in precipitation sourced from southern Indonesia around the Java Sea, which is strongest during the boreal summer, and a shift to more local precipitation sources $(\sim 100 \mathrm{~km})$. The overall size of the source region in the control simulation is larger. Around Lake Tanganyika, there is a distinct change in the source of precipitation, from an Indian Ocean dominated source to a strongly continental and Atlantic influenced source. The mean hosing TD is $\sim 820 \mathrm{~km}$ less than during the control simulation. In addition, there is an increase in the proportion of recycled non-fractionated vapour by $\sim 6 \%$.

Analyses of VSDs to other sites, including Moomi cave in Yemen (Fig. 7), and Liang Luar cave, southern Indonesia, indicate relatively local precipitation sources with minimal hosing impact on VSDs.

\section{Site classifications}

Given the impact of hosing on climate in these simulations, we attempt to classify each site into one of five categories (Table 1) by which mechanism is most closely associated with $\delta^{18} \mathrm{O}_{p}$ variability for the abrupt, H-type events simulated here. Secondary $\delta^{18} \mathrm{O}_{p}$ effects are also identified. It is possible that these characterisations could be different for different timescales and for different types of variability.

These categorisations include Type-1, where local precipitation and isotopic changes are consistent with the amount effect relationship. Type-2 sites occur where regional upwind hydrological changes, such as in monsoon intensity, are consistent with a nonlocal amount effect. For Type-2 sites, hydrological changes are not equally important throughout the entirety of the VSD and variations on the upwind fringes are less significant as little vapour reaching the site of rainout passes through the precipitation events on the upwind VSD periphery. Alternatively, Type-3 sites are characterised by significant vapour source shifts, rather than $\delta^{18} \mathrm{O}_{p}$ amount effect variability. Type-4 localities are defined where large shifts in the seasonality of precipitation produce corresponding $\delta^{18} \mathrm{O}_{p}$ changes. Sites are classified as Type-5 where there is no explanation for isotope signals in terms of precipitation, VSDs or seasonality changes. Finally, model results are used to indicate whether the measured isotopic changes are representative of a broader climatic region in which they lie.

\subsection{China}

Chinese speleothem $\delta^{18} \mathrm{O}$ variability is commonly interpreted as primarily controlled by rainfall seasonality and changes in the intensity of the summer season rainfall (Wang et al., 2001, 2008; Zhou et al., 2008), analogous to the Type4 category. Local amount effect changes are considered to be a secondary driver of $\delta^{18} \mathrm{O}_{p}$ (Wang et al., 2001; Zhou et al., 2008).

The simulated large-scale hydrological changes in the EAM region, together with the modelled spatial complexity of nearby zero precipitation and $\delta^{18} \mathrm{O}_{p}$ contour lines indicate Chinese sites are best classified as Type-2, with $\delta^{18} \mathrm{O}_{p}$ variability consistent with nonlocal amount effects such as upwind regional hydrological changes that alter $\delta^{18} \mathrm{O}$ prefractionation.

There is a small decrease in hosing-driven Asian monsoon intensity (defined by the zonal wind shear WY index) during the summer months (JJA). This is associated with relatively local precipitation sources and enriched precipitation. There is a seasonally robust enrichment in incoming $\delta^{18} \mathrm{O}_{v}\left(\delta^{18} \mathrm{O}\right.$ water vapour) to the region (ANN $\Delta \delta^{18} \mathrm{O}_{v} \sim 1.9 \%$, JJA $\Delta \delta^{18} \mathrm{O}_{v} \sim 0.2 \%$ o, DJF $\Delta \delta^{18} \mathrm{O}_{v} \sim 1.3 \%$ o), relative to estimate control $\delta^{18} \mathrm{O}_{v}$ of $-15 \%$. Summer monsoon weakening is accompanied by a decrease in $\delta^{18} \mathrm{O}_{v}$ transported landward from oceanic sources, with a reduction in transport from the tropical west Pacific. There is a hosing-driven decrease in regional incoming water vapour in summer by $\sim 78 \times 10^{6} \mathrm{~kg} / \mathrm{s}$ (or $\sim 4 \%$ ). During the summer months, the vapour originating from the Indian Ocean sector traverses the area of significant precipitation decreases over Bangladesh and Southeast Asia (Fig. 4), resulting in less pre-fractionation.

Simulated source region shifts to China (Fig. 6), particularly vapour increases from the Bay of Bengal, may indicate also that the VSD has a secondary influence at these sites (Type-3). The gain in Bay of Bengal sourced vapour during hosing is greatest in the winter season. Conversely, decreases from this source are simulated in summer, although larger source reductions from the East China Sea occur. The VSD shift is associated with slight evaporative source enrichment relative to control (ANN $\delta^{18} \mathrm{O}_{\text {source }} \sim 0.3 \%$ o).

The spatial complexity of regional precipitation amount and $\delta^{18} \mathrm{O}_{p}$ changes indicates that Chinese sites are not typically Type-1, local amount effect dominated. Modelled $\delta^{18} \mathrm{O}$ changes are not singularly consistent with changes in the relative seasonal proportions of rainfall over these regions and hence these sites are not considered typically Type- 4 , seasonality driven. In addition, the modern seasonal cycle does not seem to be a good analogue for hosing-driven VSD changes over China, and this is likely also the case for $\delta^{18} \mathrm{O}_{p}$ variability. 
Table 3. Summary of modelled hosing precipitation source region impacts on ultimate $\delta^{18} \mathrm{O}_{p}$, (control, $0 \mathrm{k}$, and hosing anomalies, $\Delta \mathrm{Hosing}$ ), including estimated initial source region composition $\left(\delta^{18} \mathrm{O}_{\text {source}}\right)$, fraction of precipitation derived from continental recycling, hosing change in mean precipitation source latitude and longitude, mean vapour transport distance and suggested site classifications including primary $\delta^{18} \mathrm{O}_{p}$ controls and secondary effects.

\begin{tabular}{|c|c|c|c|c|c|c|c|c|c|}
\hline \multirow[b]{2}{*}{ Location } & \multirow[b]{2}{*}{$\begin{array}{r}\Delta \delta^{18} \mathrm{O}_{p} \\
(\% o)\end{array}$} & \multicolumn{2}{|c|}{$\begin{array}{c}\text { Initial source } \\
\delta^{18} \mathrm{O}_{\text {source }}(\% o)\end{array}$} & \multicolumn{2}{|c|}{$\begin{array}{l}\text { Continental } \\
\text { recycling }(\%)\end{array}$} & \multicolumn{2}{|c|}{$\begin{array}{l}\text { Mean vapour transport } \\
\text { distance }(\mathrm{km})\end{array}$} & \multirow[b]{2}{*}{$\begin{array}{r}\Delta \text { Hosing precip } \\
\text { source mean lat,lon }\end{array}$} & \multirow[b]{2}{*}{$\begin{array}{l}\text { Site } \\
\text { classification }\end{array}$} \\
\hline & & Ok & $\Delta$ Hosing & 0k & $\Delta$ Hosing & Ok & $\Delta$ Hosing & & \\
\hline GRIP & -3.9 & -2.5 & -4.2 & 27 & 9 & 3035 & 7 & $-0^{\circ} 3^{\prime},-1^{\circ} 3^{\prime}$ & \\
\hline Byrd & 0.0 & -7.1 & -0.1 & 27 & -1 & 3206 & 262 & $0^{\circ} 3^{\prime}, 10^{\circ} 5^{\prime}$ & \\
\hline Taylor Dome & -0.6 & -6.8 & -0.1 & 23 & 0 & 2323 & -28 & $-0^{\circ} 4^{\prime},-2^{\circ} 5^{\prime}$ & \\
\hline Hulu cave & 0.0 & 1.5 & 0.0 & 38 & -1 & 1143 & -51 & $0^{\circ} 1^{\prime}, 0^{\circ} 3^{\prime}$ & Type-2/3 \\
\hline Songjia cave & 1.0 & 1.4 & 0.5 & 57 & 1 & 1250 & 17 & $-0^{\circ} 1^{\prime},-0^{\circ} 1^{\prime}$ & Type-2/3 \\
\hline Sanbao cave & 0.4 & 1.6 & 0.2 & 48 & 0 & 1073 & 30 & $-0^{\circ} 2^{\prime},-0^{\circ} 3^{\prime}$ & Type- $2 / 3$ \\
\hline Borneo & 0.6 & -1.0 & 0.2 & 25 & 2 & 479 & -102 & $-0^{\circ} 1^{\prime},-1^{\circ}$ & Type- $1 / 3$ \\
\hline Liang Luar cave & -0.7 & 0.0 & -0.1 & 20 & -1 & 108 & 195 & $0^{\circ} 1^{\prime},-1^{\circ} 5^{\prime}$ & Type-1 \\
\hline Moomi cave & 0.2 & 2.0 & 0.3 & 18 & 3 & 296 & -235 & $0^{\circ} 4^{\prime},-2^{\circ} 9^{\prime}$ & Type- $1 / 2$ \\
\hline Soreq cave & -1.2 & 4.8 & -1.5 & 55 & -3 & 903 & 43 & $0^{\circ} 5^{\prime}, 0^{\circ} 1^{\prime}$ & \\
\hline Lake Tanganyika & 1.3 & 0.9 & 0.3 & 62 & 6 & 1154 & -819 & $0^{\circ} 1^{\prime},-7^{\circ} 3^{\prime}$ & Type-3 \\
\hline Rio Grande do Norte & -2.8 & 1.0 & -1.8 & 15 & 0 & 1339 & 12 & $1^{\circ} 3^{\prime}, 0^{\circ} 1^{\prime}$ & Type-1 \\
\hline Toca da Boa Vista & -3.5 & 2.4 & -2.1 & 27 & 2 & 1179 & 27 & $0^{\circ} 5^{\prime}, 0^{\circ} 4^{\prime}$ & Type-1 \\
\hline Santana cave & -3.2 & 6.9 & -2.6 & 0 & 957 & 54 & & $0^{\circ} 2^{\prime}, 0^{\circ} 3^{\prime}$ & Type-1 \\
\hline Botuverá cave & -1.5 & 4.8 & -1.5 & 28 & 0 & 411 & 34 & $0^{\circ} 9^{\prime}, 0^{\circ} 2^{\prime}$ & Type-1 \\
\hline Cave of the Bells & -1.2 & 1.7 & -0.3 & 30 & 2 & 1259 & -187 & $-2^{\circ} 1^{\prime},-5^{\circ} 1^{\prime}$ & \\
\hline Poleva cave & -2.9 & 2.1 & -2.6 & 46 & -2 & 783 & 38 & $-1^{\circ},-2^{\circ} 2^{\prime}$ & \\
\hline China region & 0.6 & 1.5 & 0.3 & 50 & 0 & 1261 & 5 & $0^{\circ} 1^{\prime},-0^{\circ} 6^{\prime}$ & \\
\hline Brazil region & -2.9 & 2.1 & -1.8 & 23 & 1 & 1312 & 41 & $0^{\circ} 5^{\prime}, 0^{\circ} 9^{\prime}$ & Type-1 \\
\hline
\end{tabular}

Ultimately, sites within China present a complex spatial pattern of precipitation changes. The Chinese VSD is complex and straddles an area of variable hosing-driven precipitation changes across both China and the west Pacific. It should also be noted that the small magnitude of isotopic changes occurring near the coast suggests that cave sites may not necessarily be representative of regional processes. Similarly, proxy sites are situated outside the area of peak EAM influence and are not necessarily indicative of broader changes to the south or west.

\subsection{Brazil}

Interpretations from Rio Grande do Norte, Santana and Botuverá caves in South America predominantly employ the amount effect relationship (Type 1) (Wang et al., 2006; Cruz et al., 2009). Additionally, the seasonality of precipitation is cited as a secondary $\delta^{18} \mathrm{O}_{p}$ driver, through associated changes in the evaporative origin of precipitation (Cruz et al., 2005, 2006a).

In agreement with these interpretations, simulated hosing precipitation increases and depleted $\delta{ }^{18} \mathrm{O}_{p}$ over Brazil are consistent with categorisation as Type-1 sites. Regional precipitation changes are associated with the simulated hosing southward ITCZ shift, which is most prevalent over the Atlantic and impact eastern tropical South America precipitation.

Although caves within the Brazil region are the clearest examples of Type-1, local amount effect dominated sites, regional hosing-driven increases in the landward transport of water vapour are also simulated. Using the broadened WY wind shear index, monsoon intensification is modelled over the SM region (Fig. 5), impacting both precipitation amount and $\delta^{18} \mathrm{O}_{p}$. Increases in vapour flux under a strengthened monsoon system also correspond to generally light $\delta^{18} \mathrm{O}$ values $\left(\Delta \delta^{18} \mathrm{O}_{v} \sim-1.5 \%\right.$, compared to control $\delta^{18} \mathrm{O}_{v} \sim-16 \%$ ) in vapour transported from the relatively depleted tropical Atlantic landward into northeastern South America. The relative depletion of the Atlantic source region $\left(\Delta \delta^{18} \mathrm{O}_{\text {source }} \sim-1.9 \%\right.$ ), from the injection of isotopically light surface waters also contributes to anomalously depleted precipitation in the region.

South American cave sites are situated along the Atlantic coast, removed from the peak of monsoonal rainfall and are not necessarily regionally representative. Opposite-signed hosing-driven isotopic and precipitation anomalies (Figs. 3 and 4) are simulated directly west of the Rio Grande do Norte, Santana and Botuverá cave sites. This regional antiphasing is related to the location of the ITCZ, which is displaced during the hosing simulation. 


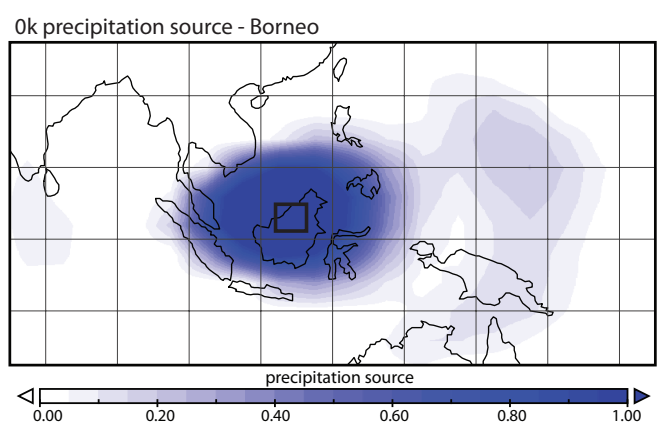

Ok precipitation source - Lake Tanganiyka, East Africa

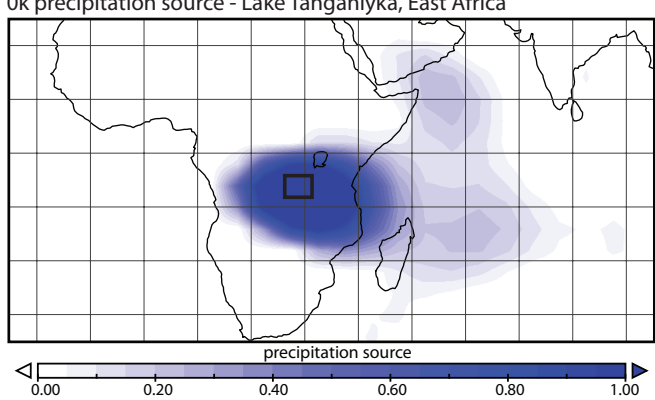

Ok precipitation source - Moomi cave, Yemen

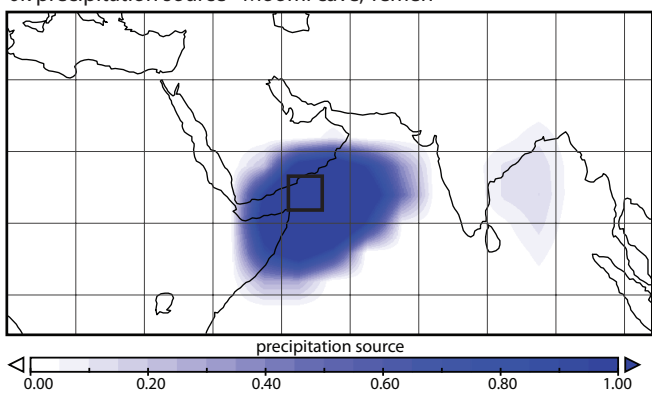

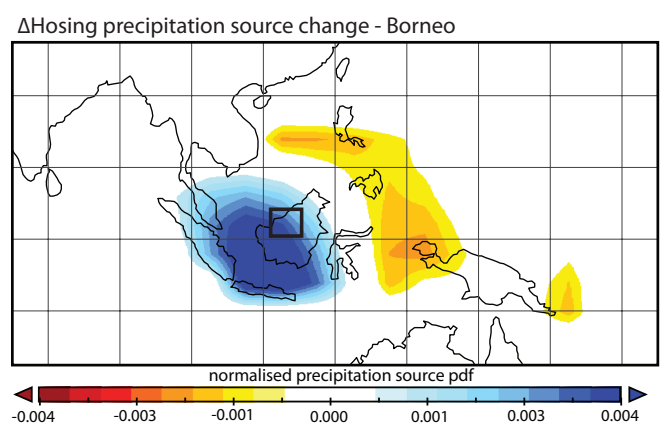

$\Delta$ Hosing precipitation source chanqe - Lake Tanqaniyka, East Africa

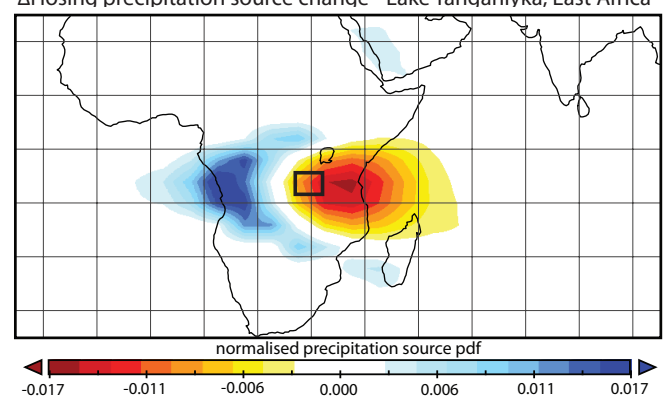

$\triangle$ Hosing ANN precipitation source change - Moomi cave, Yemen

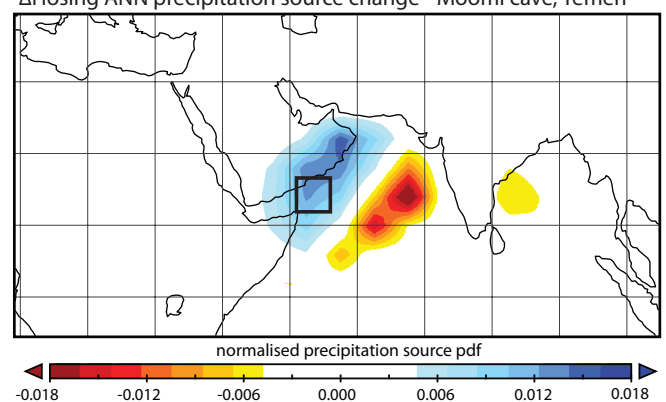

Fig. 7. Control precipitation source distributions (Ok) and hosing source region precipitation anomalies for Borneo (top, Partin et al., 2007), Lake Tanganyika (middle, Tierney et al., 2008) and Moomi cave, Yemen, (bottom, Shakun et al., 2007) proxy sites. Solid rectangular boxes indicate the location of end member precipitation. VSDs are unitless probability density functions, normalised by the maximum probability density.

\subsection{Borneo}

Isotopic enrichment in Borneo speleothems during $\mathrm{H}$ events is interpreted as rainfall amount changes (Type-1) driven by fluctuations in the mean position and intensity of the ITCZ (Partin et al., 2007). Simulated average decreases in precipitation (ANN $-0.5 \mathrm{~mm} /$ day; JJA $0.9 \mathrm{~mm} /$ day; DJF -2.4 $\mathrm{mm} /$ day) and $\delta^{18} \mathrm{O}_{p}$ enrichment (ANN $\Delta \delta^{18} \mathrm{O}_{p} 0.6 \%$; JJA $\Delta \delta^{18} \mathrm{O}_{p} 0 \%$; DJF $\Delta \delta^{18} \mathrm{O}_{p} 0.6 \%$ ) over the northern Warm Pool region are broadly consistent with interpretations of regionally coherent drying during $\mathrm{H}$ events under the amount effect. As precipitation and isotopic anomalies are consistent with the amount effect, Borneo is classified as Type-1.

In these hosing simulations, Borneo lies close to the zero hosing precipitation and $\delta^{18} \mathrm{O}$ contours, particularly in summer (JJA) and may have secondary, nonlocal $\delta^{18} \mathrm{O}_{p}$ controls. The VSD indicates precipitation to Borneo has a relatively local source, which does not support Type-2 categorisation (Fig. 7). There may be a secondary effect of transport distance changes on Borneo $\delta^{18} \mathrm{O}_{p}$ (Type-3, source region influenced) as mean TD decreases by $\sim 100 \mathrm{~km}$, likely resulting in less rain-out of heavy isotopes during transport and yielding enriched $\delta^{18} \mathrm{O}_{p}$. Similarly, the simulated source shift tends to bring moisture from a sector of enriched vapour $\left(\Delta \delta^{18} \mathrm{O}_{\text {source }} \sim-0.2 \%\right.$ o). Furthermore, the difference in the direction of precipitation amount changes between summer and winter during the hosing simulation highlights possible Type-4 seasonality effects.

Overall, Borneo is predominantly a Type- 1 site, with changes in TD (Type-3) a secondary contributor to variability. 


\subsection{Lake Tanganyika}

The amount effect is cited as the primary control on isotopic variability in the Lake Tanganyika isotope record, with moisture source origin and transport history a lesser consideration (Tierney et al., 2008). Here, we simulate enrichment in annual average local precipitation (ANN $\Delta \delta^{18} \mathrm{O}_{p} 1.3 \%$; JJA $\Delta \delta^{18} \mathrm{O}_{p} ; 0.1 \%$; DJF $\Delta \delta^{18} \mathrm{O}_{p} 2.4 \%$ ), together with seasonally variable precipitation changes (ANN $0 \mathrm{~mm} /$ day; JJA $0.1 \mathrm{~mm} /$ day; DJF $-0.9 \mathrm{~mm} /$ day). Although annually this site lies on a front of zero precipitation changes and average simulated rainfall amount within the overlying gridbox is unchanged, regional increases associated with the ITCZ shift are simulated (ANN $0.2 \mathrm{~mm} /$ day; JJA $0.3 \mathrm{~mm} /$ day; DJF $-0.1 \mathrm{~mm} /$ day). Overall, modelled hosing-driven precipitation changes are inconsistent with site interpretations of dry $\mathrm{H}$ events.

The significant westward shift of the VSD during the hosing simulation suggests that Lake Tanganyika is a Type-3 site, whereby source shifts are most strongly associated with $\delta^{18} \mathrm{O}_{p}$ changes (Fig. 7). The mean vapour TD is reduced by $\sim 800 \mathrm{~km}$ during the hosing simulation, which diminishes rain-out and pre-fractionation, with the mean longitude of the VSD shifting $\sim 7.5^{\circ}$ westward. Also, there is an overall increase in the proportion of non-fractionated recycled continental vapour by $\sim 6 \%$. The estimated initial composition of the hosing source to Lake Tanganyika is $\sim 0.3 \%$ o more enriched relative to the control. Simulated transport and VSD changes are associated with enriched water vapour composition and likely dominate the hosing-driven $\delta^{18} \mathrm{O}_{p}$ anomaly. Modern observations also indicate that enriched moisture originating from the Congo Basin contributes to comparatively high observed $\delta^{18} \mathrm{O}_{p}$ values over eastern equatorial Africa (Levin et al., 2009).

The increased contribution of the western continental and Atlantic source during hosing is regionally robust throughout SH tropical eastern Africa and likely results from the increase in SST in the south Atlantic, which is an ensemblewide hosing feature (Stouffer et al., 2006). VSD shifts and associated simulated changes in $\delta^{18} \mathrm{O}_{p}$ do not support suggestions that the source region to sites dominated by moisture from the Indian Ocean were insensitive to $\mathrm{H}$-event climatic changes (Verschuren et al., 2009).

\subsection{Moomi cave, Yemen}

Oxygen isotopic variability at Moomi cave is interpreted in terms of rainfall amount, driven by changes in the latitudinal position of the ITCZ and the intensity of ITCZ convection (Shakun et al., 2007). The interpretation of $\delta^{18} \mathrm{O}_{p}$ enrichment at this site as an abrupt drying event is consistent with simulated decreases in hosing precipitation (ANN $-0.1 \mathrm{~mm} /$ day; JJA $-0.2 \mathrm{~mm} /$ day; DJF $-0.1 \mathrm{~mm} /$ day). Furthermore, the modelled $\delta^{18} \mathrm{O}_{p}$ enrichment (ANN $\Delta \delta^{18} \mathrm{O}_{p}$
$0.2 \%$; JJA $\Delta \delta^{18} \mathrm{O}_{p} 0.4 \%$; DJF $\Delta \delta^{18} \mathrm{O}_{p} 0.1 \%$ ) is consistent with local amount effect (Type-1).

Moomi cave resides near zero anomaly lines for hosing precipitation and $\delta^{18} \mathrm{O}_{p}$, isotopic variability may record more regional amount effects (Type-2). There is a decrease in rainfall occurring within the Moomi VSD during the hosing simulation, potentially reducing the degree of isotopic prefractionation occurring and increasing $\delta^{18} \mathrm{O}_{p}$ enrichment. The simulated VSD indicates precipitation sources are relatively local (Fig. 7).

\subsection{Liang Luar cave, Indonesia}

In southern Indonesia, the coincidence of growth hiatuses with $\mathrm{H} 2$ and $\mathrm{H} 3$ may not reflect a suggested local drying (Lewis et al., 2010). Hosing simulations indicate robust yearround precipitation increases at this site (ANN $0.8 \mathrm{~mm} /$ day; JJA $0.8 \mathrm{~mm} /$ day; DJF $0.6 \mathrm{~mm} /$ day), in consistent with wet events reported from northeastern Australia (Muller et al., 2008) and Indonesia (Westaway et al., 2007). Precipitation increases may lead to changes in cave hydrology that preclude deposition of calcite (Fairchild et al., 2006).

Generally, the simulated rainfall increases and concomitant $\delta^{18} \mathrm{O}_{p}$ depletion (ANN $\Delta \delta^{18} \mathrm{O}_{p}-0.7 \%$; JJA $\Delta \delta^{18} \mathrm{O}_{p}$ $-0.8 \%$; DJF $\Delta \delta^{18} \mathrm{O}_{p}-0.7 \%$ o) are consistent with a Type- 1 , local amount effect classification. Furthermore, the VSD indicates local evaporative sources, with minimal long distance vapour transport. Although this site lies nearby to hosing contours of zero $\delta^{18} \mathrm{O}_{p}$ and precipitation changes, it is representative of regional SH hydrological changes, including increased, isotopically depleted rainfall under an intensified Australian summer monsoon.

\section{Discussion}

Simulated hosing climatic changes over different proxy sites indicate a range of $\delta^{18} \mathrm{O}_{p}$ controls that occur on a variety of spatial scales. It should be noted that the characterisation of sites might vary for different types of climatic changes occurring on other timescales. The categorisation of sites indicates that for those residing within the tropical weather regime year-round, such as those situated around the Warm Pool region (Borneo and Liang Luar cave), Moomi cave in Yemen and within northeastern Brazil, simulated $\delta^{18} \mathrm{O}_{p}$ responds primarily to local rainfall amount changes. Although the distinction between Type- 1 and Type- 2 sites is at times subtle, Type- 2 classification is adopted for those influenced by more regional hydrological changes, such as monsoon intensification or weakening.

We distinguish between local precipitation amount and monsoon intensity using the WY index of zonal wind shear changes. The WY index for the Asian region is more closely associated with regional precipitation changes and is more useful than local precipitation changes alone for describing $\delta^{18} \mathrm{O}_{p}$ changes over China. In this region, local precipitation 
amount and monsoon intensity are not necessarily synonymous. Over China, simulated local precipitation and $\delta^{18} \mathrm{O}_{p}$ exhibit a complex spatial pattern of changes during hosing and hydrological responses are seasonally and spatially variable. However, modelled $\delta^{18} \mathrm{O}_{p}$ enrichment is associated with monsoonal upwind changes within the VSD and local rainfall over the defined Chinese region (Fig. 6) is likely influenced by nonlocal pre-fractionation.

In addition, speleothems do not directly record $\delta^{18} \mathrm{O}_{p}$ variability. Though incorporating water isotopes tracers brings ModelE a step closer to allowing model-proxy comparisons, there are multiple processes impacting $\delta^{18} \mathrm{O}_{\text {calcite }}$ that can be site specific. These include $\delta^{18} \mathrm{O}_{p}$ and cave temperature variability, and internal cave hydrological dynamics (Fairchild et al., 2006). Changes in the epikarst and cave environment are usually minor $\delta^{18} \mathrm{O}_{\text {calcite }}$ drivers, however, some monsoon-influenced sites undergo a $>5{ }^{\circ} \mathrm{C}$ (equivalent to $>\sim 1 \%$ o $\delta^{18} \mathrm{O}_{\text {calcite }}$ ) seasonal temperature cycle (Johnson et al., 2006), which complicate primary climatic signals. Also, at sites with erratic monitoring programmes, it may be unclear if calcite growth integrates an annual or seasonal signal, making model comparisons difficult. Site-specific forward models incorporating calcite precipitation processes could further improve proxy-model $\Delta \delta^{18} \mathrm{O}$ comparisons.

The experimental design here represents a very idealised version of a Heinrich event. We apply a uniform freshwater injection across a large Atlantic area, which is not necessarily representative of iceberg discharge into the North Atlantic (Hemming, 2004), though it does create a similar scenario where the North Atlantic region cools by about the right amount. Modelled $\delta^{18} \mathrm{O}_{p}$ excursions are not consistent with proxy changes in all records, and may occur over areas characterised by steep topography or where the simulation of precipitation fields is poor. Mismatches over sites such as Hulu and Soreq caves and Cave of Bells are attributed to inadequacies in the coarse model resolution utilised. Site $\delta^{18} \mathrm{O}_{p}$ categorisation is only attempted for tropical locations where simulated and measured isotopic values broadly agree.

This study is enhanced by the incorporation of general VSD tracers into the model. However, in order to diagnose comprehensively the relative contributions of different controls on $\delta^{18} \mathrm{O}_{p}$, specific $\mathrm{H}_{2}^{18} \mathrm{O}$ source distribution tracers are required. With additional VSD tracers for the isotopes themselves, the impact of TD and source region changes on precipitation composition could be addressed more quantitatively. However, these tracers are prohibitively expensive to run. Additions to VSD tracers may allow the cause of mismatches between simulated and reconstructed $\delta^{18} \mathrm{O}$ changes to be identified. Also, site classifications in this study do not explicitly account for the mixing of air from spatially disperse evaporative sources along the transport route. The degree of mixing encountered by an air mass en route from evaporative source to the site of precipitation is also an important control on $\delta^{18} \mathrm{O}_{p}$, although this is difficult to constrain. Previously, the impact of circulation strength changes on $\delta^{18} \mathrm{O}_{p}$ has been better constrained through model sensitivity studies (Noone, 2008), and future analyses adopting similar approaches may clarify the impact of mixing during transport on $\delta^{18} \mathrm{O}_{p}$ and provide a further type categorisation.

\section{Conclusions}

We simulate a shutdown of the THC after freshwater injection to the North Atlantic, as an analogue to a Heinrich event. Modelled hosing precipitation fields demonstrate a distinct fingerprint of climatic change, including a southward shift in the ITCZ, in agreement with PMIP multi-model results (Stouffer et al., 2006). Simulated hosing climatic perturbations include a pattern of depleted $\delta^{18} \mathrm{O}_{p}$ values across the tropical southern Pacific, Atlantic and Indian Oceans, the West Pacific Warm Pool, eastern South America and southern Africa. Conversely, enriched isotopic values are modelled over most of southern Asia and central Africa, corresponding to increased precipitation around the ITCZ. Furthermore, changes in monsoon intensity and associated water vapour fluxes are modelled, including a SM intensification and a small reduction in Asian monsoon. The dynamical index utilised here (WY index of zonal wind shear anomalies) is useful in diagnosing monsoon changes. Quantifying monsoonal changes in this way disambiguates the use of this term and reinforces that monsoon changes do not necessarily equate to local rainfall amount variability.

Water isotopes archives demonstrate a fairly coherent pattern of isotopic changes during Heinrich events, where spatially proximate measurement sites show congruent signals. Comparisons of reconstructed Heinrich event $\delta^{18} \mathrm{O}$ and simulated hosing $\delta^{18} \mathrm{O}_{p}$ excursions indicate areas of broad modeldata agreement, particularly over China and Brazil. To the extent that simulated patterns of change agree with proxy reconstructions, model results can confirm whether the measured isotope changes are representative of a broader climatic region in which they lie. Also, this spatial representation provides another way to constrain modelled NADW responses (e.g. LeGrande et al., 2006).

As $\delta^{18} \mathrm{O}_{p}$ integrates a complete air mass history, from source to rain-out, speleothems record a complex history of climatic change and require detailed interpretations. Sitespecific VSDs are shown to be a valuable circulation diagnostic and should be considered when interpreting hydrological changes from water isotope proxy records. We attempt to categorise proxy sites according to the dominant influences on simulated $\delta^{18} \mathrm{O}_{p}$ variability, including changes in local and nonlocal rainfall amount, precipitation seasonality and VSDs. Site classification is complicated in some instances and most sites exhibit multiple influences and secondary $\delta^{18} \mathrm{O}_{p}$ effects are identified.

For coastal sites or tropical areas associated with the ITCZ rains, such as around northeastern Brazil and the Warm Pool, isotopic variability likely reflects local rainfall intensity changes by the amount effect (Type-1). Other sites, such as 
within China, lie near contours of zero hosing $\delta^{18} \mathrm{O}_{p}$ or precipitation changes and record a nonlocal amount effect due to upwind changes (Type-2). Modelled VSDs are useful in identifying nonlocal amount effect influences on $\delta^{18} \mathrm{O}_{p}$. Finally, Lake Tanganyika is categorised as Type-3, where significant westward hosing-driven precipitation source shifts control $\delta^{18} \mathrm{O}_{p}$ variability through changes in the degree of pre-fractionation and the relative enrichment of the nonfractionating continental moisture source. No sites are primarily characterised by seasonality $\delta^{18} \mathrm{O}_{p}$ changes (Type-4), which has been utilised in proxy interpretations.

Acknowledgements. We thank NASA GISS for institutional support. NSF ATM 07-53868 supports ANL and travel for SCL. This study was assisted by APA/ASS/JAE Scholarships and travel funding from Paterson Fellowship/ANU Vice-Chancellor/M. Gagan to SCL. We thank the referees for their constructive comments on the monsoon indices and for the opportunity to clarify the earlier version of this paper.

Edited by: E. Wolff

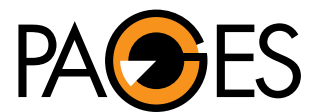

The publication of this article was sponsored by PAGES.
Bowen, G. J.: The Online Isotopes in Precipitation Calculator, version 2.2: http://www.waterisotopes.org, last access: 28 August 2009, 2009.

Broecker, W. S.: Paleocean circulation during the last deglaciation: a bipolar seesaw?, Paleoceanography, 13, 119-121, 1998.

Brown, J.: The response of stable water isotopes in precipitation and the surface ocean to tropical climate variability, Doctor of Philosophy, School of Earth Sciences, University of Melbourne, Melbourne, 2004.

Cobb, K. M., Adkins, J. F., Partin, J. W., and Clark, B.: Regionalscale climate influences on temporal variations of rainwater and cave dripwater oxygen isotopes in northern Borneo, Earth Planet. Sc. Lett., 263, 207-220, doi:10.1016/j.eps1.2007.08.024, 2007.

Cole, J. E., Rind, D., Webb, R. S., Jouzel, J., and Healy, R.: Climatic controls on interannual variability of precipitation $\delta 18 \mathrm{O}$ : Simulated influence of temperature, precipitation amount, and vapor source region, J. Geophys. Res., 104, 14,223-214,223, doi:10.1029/1999JD900182, 1999.

Constantin, S., Bojar, A.-V., Lauritzen, S.-E., and Lundberg, J.: Holocene and late Pleistocene climate in the sub-Mediterranean continental environment; a speleothem record from Poleva Cave (southern Carpathians, Romania), Palaeogeogr. Palaeoecl., 243, 3-4, doi:10.1016/j.palaeo.2006.08.001, 2007.

Cruz, F. W., Burns, S. J., Karmann, I., Sharp, W. D., Vuille, M., Cardoso, A. O., Ferrari, J. A., Silva Dias, P. L., and Viana, O.: Insolation-driven changes in atmospheric circulation over the past 116000 years in subtropical Brazil, Nature, 434, 63-66, doi:10.1038/nature03365, 2005 .

Cruz, F. W., Vuille, M., Burns, S. J., Wang, X., Cheng, H., Werner, M., Lawrence Edwards, R., Karmann, I., Auler, A. S., and Nguyen, H.: Orbitally driven east-west antiphasing of South American precipitation, Nature Geosci., 2, 210-214, doi:10.1038/ngeo444, 2009.

Cruz, F. W. J., Burns, S. J., Karmann, I., Sharp, W. D., and Vuille, M.: Reconstruction of regional atmospheric circulation features during the late Pleistocene in subtropical Brazil from oxygen isotope composition of speleothems, Earth Planet. Sc. Lett., 248 , 495-507, doi:10.1016/j.eps1.2006.06.019, 2006a.

Cruz, F. W. J., Burns, S. J., Karmann, I., Sharp, W. D., Vuille, M., and Ferrari, J. A.: A stalagmite record of changes in atmospheric circulation and soil processes in the Brazilian subtropics during the Late Pleistocene, Quaternary Sci. Rev., 25, 2749-2761, doi:10.1016/j.quascirev.2006.02.019, 2006b.

Dansgaard, W.: Stable isotopes in precipitation, Tellus, 16, 436468, 1964.

Dong, B. W. and Sutton, R. T.: Adjustment of the coupled ocean-atmosphere system to a sudden change in the Thermohaline Circulation, Geophys. Res. Lett., 29(15), 1728, doi:10.1029/2002GL015229, 2002.

Druyan, L. M. and Koster, R. D.: Sources of Sahel Precipitation for Simulated Drought and Rainy Seasons, J. Climate, 2, 1438 1446, doi:10.1175/1520-0442, 1989.

Fairchild, I. J., Smith, C. L., Baker, A., Fuller, L., Spötl, C., Mattey, D., McDermott, F., and E. I. M. F: Modification and preservation of environmental signals in speleothems, Earth-Sci. Rev., 75, 105-153, doi:10.1016/j.earscirev.2005.08.003, 2006.

Gat, J. R.: Oxygen and hydrogen isotopes in the hydrologic cycle, Annu. Rev. Earth Pl. Sc., 24, 225-262, doi:10.1146/annurev.earth.24.1.225, 1996. 
Griffiths, M. L., Drysdale, R. N., Gagan, M. K., Zhao, J. x., Ayliffe, L. K., Hellstrom, J. C., Hantoro, W. S., Frisia, S., Feng, Y. X., Cartwright, I., Pierre, E. S., Fischer, M. J., and Suwargadi, B. W.: Increasing Australian-Indonesian monsoon rainfall linked to early Holocene sea-level rise, Nature Geosci., 2, 636-639, doi:10.1038/ngeo605, 2009.

GRIP Members: Climate instability during the last interglacial period recorded in the GRIP ice core, Nature, 364, 203-207, doi:10.1038/364203a0, 1993.

Grootes, P. M., Steig, E. J., Stuiver, M., Waddington, E. D., Morse, D. L., and Nadeau, M.-J.: The Taylor Dome Antarctic 180 Record and Globally Synchronous Changes in Climate, Quaternary Res., 56, 289-298, doi:10.1006/qres.2001.2276, 2001.

Hansen, J., Sato, M., Ruedy, R., Kharecha, P., Lacis, A., Miller, R., Nazarenko, L., Lo, K., Schmidt, G. A., Russell, G., Aleinov, I., Bauer, S., Baum, E., Cairns, B., Canuto, V., Chandler, M., Cheng, Y., Cohen, A., Del Genio, A., Faluvegi, G., Fleming, E., Friend, A., Hall, T., Jackman, C., Jonas, J., and et al.: Climate simulations for 1880-2003 with GISS modelE, Clim. Dynam., 29, 661-696, doi:10.1007/s00382-007-0255-8, 2007.

Heinrich, H.: Origin and consequence of cyclic ice rafting in the northeast Atlantic Ocean during the past 130000 years, Quat. Res., 29, 142-152, doi:10.1016/0033-5894(88)90057-9, 1988.

Hemming, S. R.: Heinrich events: massive late Pleistocene detritus layers of the North Atlantic and their global climate imprint, Rev. Geophys., 42, RG1005, doi:10.1029/2003RG000128, 2004.

IAEA/WMO: Global Network of Isotopes in Precipitation. The GNIP Database: http://isohis.iaea.org, last access: 28 August 2009, 2006.

Indermühle, A., Monnin, E., Stauffer, B., Stocker, T. F., and Wahlen, M.: Atmospheric $\mathrm{CO}_{2}$ concentration from 60 to 20 kyr BP from the Taylor Dome Ice Core, Antarctica, Geophys. Res. Lett., 27, 735-738, doi:10.1029/1999g1010960, 2000.

Johnsen, S., Dansgaard, W., and White, J. W. C.: The origin of Arctic precipitation under present and glacial conditions, Tellus B, 41, 452-468, 1989.

Johnson, K. R., Hu, C., Belshaw, N. S., and Henderson, G. M.: Seasonal trace-element and stable-isotope variations in a Chinese speleothem: The potential for high-resolution paleomonsoon reconstruction, Earth Planet. Sc. Lett., 244, 394-407, doi:10.1016/j.epsl.2006.01.064, 2006.

Joussaume, S., Sadourny, R., and Vignal, C.: Origin of precipitating water in a numerical simulation of the July climate, Ocean-Air Interactions, 1, 43-56, 1986.

Jouzel, J. and Koster, R. D.: A reconsideration of the initial conditions used for stable water isotope models, J. Geophys. Res., 101(D17), 22933-22938, doi:10.1029/96JD02362, 1996.

Jouzel, J., Alley, R. B., Cuffey, K. M., Dansgaard, W., Grootes, P., Hoffmann, G., Johnsen, S. J., Koster, R. D., Peel, D., Shuman, C. A., Stievenard, M., Stuiver, M., and White, J.: Validity of the temperature reconstruction from water isotopes in ice cores, J. Geophys. Res., 102, 26471-26487, doi:10.1029/97jc01283, 1997.

Keigwin, L. D. and Lehman, S. J.: Deep circulation change linked to Heinrich Event 1 and Younger Dryas in a middepth North Atlantic core, Paleoceanography, 9, 185-194, 1994.

Kelley, M.: Water tracers and the hydrologic cycle in a GCM, Doctor of Philosophy, Department of Earth and Environmental Sciences, Columbia University, New York, 2003.
Koster, R., Jouzel, J., Suozzo, R., Russell, G., Broecker, W., Rind, D., and Eagleson, P.: Global sources of local precipitation as determined by the NASA/GISS GCM, Geophys. Res. Lett., 13, 121-124, 1986.

LeGrande, A. N., Schmidt, G. A., Shindell, D. T., Field, C. V., Miller, R. L., Koch, D. M., Faluvegi, G., and Hoffmann, G.: Consistent simulations of multiple proxy responses to an abrupt climate change event, Proc. Natl. Acad. Sci. U. S. A, 103, 837-842, doi:10.1073/pnas.0510095103, 2006.

LeGrande, A. N. and Schmidt, G. A.: Sources of Holocene variability of oxygen isotopes in paleoclimate archives, Clim. Past, 5, 441-455, doi:10.5194/cp-5-441-2009, 2009.

Levin, N. E., Zipser, E. J., and Cerling, T. E.: Isotopic composition of waters from Ethiopia and Kenya: Insights into moisture sources for eastern Africa, J. Geophys. Res., 114, D23306, doi:10.1029/2009JD012166, 2009.

Lewis, S. C., Gagan, M. K., Ayliffe, L. K., Zhao, J.-x., Hantoro, W. S., Treble, P. C., Hellstrom, J. C., LeGrande, A. N., Kelley, M., Schmidt, G. A., and Suwargadi, B. W.: A high-resolution multiproxy stalagmite record of Heinrich event 3 impacts in southern Indonesia, in preparation, 2010.

Li, J. and Zeng, Q.: A unified monsoon index, Geophys. Res. Lett., 29(8), 1274, doi:10.1029/2001GL013874, 2002.

Manabe, S. and Stouffer, R. J.: Study of abrupt climate change by a coupled ocean-atmosphere model, Quaternary Sci. Rev., 19, 285-299, doi:10.1016/S0277-3791(99)00066-9, 2000.

Masson-Delmotte, V., Jouzel, J., Landais, A., Stievenard, M., Johnsen, S. J., White, J. W. C., Werner, M., Sveinbjornsdottir, A., and Fuhrer, K.: GRIP Deuterium Excess Reveals Rapid and Orbital-Scale Changes in Greenland Moisture Origin, Science, 309, 118-121, doi:10.1126/science.1108575, 2005.

Matthews, A., Ayalon, A., and Bar-Matthews, M.: D/H ratios of fluid inclusions of Soreq cave (Israel) speleothems as a guide to the Eastern Mediterranean Meteoric Line relationships in the last $120 \mathrm{ky}$, Chem. Geol., 166, 183-191, doi:10.1016/S00092541(99)00192-8, 2000.

Muller, J., Kylander, M., Wust, R. A. J., Weiss, D., MartinezCortizas, A., LeGrande, A. N., Jennerjahn, T., Behling, H., Anderson, W. T., and Jacobson, G.: Possible evidence for wet Heinrich phases in tropical NE Australia: the Lynch's Crater deposit, Quaternary Sci. Rev., 27, 468-475, doi:10.1016/j.quascirev.2007.11.006, 2008.

Noone, D.: The influence of midlatitude and tropical overturning circulation on the isotopic composition of atmospheric water vapor and Antarctic precipitation, J. Geophys. Res., 113, D04102, doi:10.1029/2007JD008892, 2008.

Partin, J. W., Cobb, K. M., Adkins, J. F., Clark, B., and Fernandez, D. P.: Millennial-scale trends in west Pacific warm pool hydrology since the Last Glacial Maximum, Nature, 449, 452-455, doi:10.1038/nature06164, 2007.

Paul, H. A., Bernasconi, S. M., Schmid, D. W., and McKenzie, J. A.: Oxygen isotopic composition of the Mediterranean Sea since the Last Glacial Maximum: constraints from pore water analyses, Earth Planet. Sc. Lett., 192, 1-14, doi:10.1016/S0012821X(01)00437-X, 2001.

Risi, C., Bony, S., and Vimeux, F.: Influence of convective processes on the isotopic composition ( $\mathrm{O}$ and $\mathrm{D})$ of precipitation and water vapor in the tropics: 2. Physical interpretation of the amount effect, J. Geophys. Res., 113, D19306, 
doi:10.1029/2008JD009943, 2008.

Rozanski, K., Araguas-Araguas, L., and Gonfiantini, R.: Isotopic patterns in modern global precipitation, in: Climate change in continental isotopic records, edited by: Swart, P. K., Lohmann, K. C., McKenzie, J., and Savin, S., Geophysical Monograph, 78, American Geophysical Union, Washington, DC, 1-36, 1993.

Ruiz-Barradas, A. and Nigam, S.: Great Plains Hydroclimate Variability: The View from North American Regional Reanalysis, J. Climate, 19, 3004-3010, doi:10.1175/JCLI3768.1, 2006.

Schmidt, G. A., Hoffmann, G., Shindell, D. T., and Hu, Y. Y.: Modeling atmospheric stable water isotopes and the potential for constraining cloud processes and stratosphere-troposphere water exchange, J. Geophys. Res.-Atmos., 110, D21314, doi:10.1029/2005JD005790, 2005.

Schmidt, G. A., Ruedy, R., Hansen, J. E., Aleinov, I., Bell, N., Bauer, M., Bauer, S., Cairns, B., Canuto, V., Cheng, Y., Del Genio, A., Faluvegi, G., Friend, A. D., Hall, T. M., Hu, Y. Y., Kelley, M., Kiang, N. Y., Koch, D., Lacis, A. A., Lerner, J., Lo, K. K., Miller, R. L., Nazarenko, L., Oinas, V., Perlwitz, J., Perlwitz, J., Rind, D., Romanou, A., Russell, G. L., Sato, M., Shindell, D. T., Stone, P. H., Sun, S., Tausnev, N., Thresher, D., and Yao, M. S.: Present-day atmospheric simulations using GISS ModelE: Comparison to in situ, satellite, and reanalysis data, J. Climate, 19, 153-192, doi:110.1175/JCLI3612.1171, 2006.

Schmidt, G. A., LeGrande, A. N., and Hoffmann, G.: Water isotope expressions of intrinsic and forced variability in a coupled ocean-atmosphere model, J. Geophys. Res.-Atmos., 112, D10103, doi:10.1029/2006JD007781, 2007.

Shakun, J. D., Burns, S. J., Fleitmann, D., Kramers, J., Matter, A., and Al-Subary, A.: A high-resolution, absolute-dated deglacial speleothem record of Indian Ocean climate from Socotra Island, Yemen, Earth Planet. Sc. Lett., 259, 442-456, doi:10.1016/j.epsl.2007.05.004, 2007.

Sjostrom, D. J. and Welker, J. M.: The influence of air mass source on the seasonal isotopic composition of precipitation, eastern USA, J. Geochem. Explor., 102, 103-112, doi:10.1016/j.gexplo.2009.03.001, 2009.

Stouffer, R. J., Yin, J., Gregory, J. M., Dixon, K. W., Spelman, M. J., Hurlin, W., Weaver, A. J., Eby, M., Flato, G. M., Hasumi, H., Hu, A., Jungclaus, J. H., Kamenkovich, I. V., Levermann, A., Montoya, M., Murakami, S., Nawrath, S., Oka, A., Peltier, W. R., Robitaille, D. Y., Sokolov, A., Vettoretti, G., and Weber, S. L.: Investigating the Causes of the Response of the Thermohaline Circulation to Past and Future Climate Changes, J. Climate, 19, 1365-1387, doi:10.1175/JCLI3689.1, 2006.

Tierney, J. E., Russell, J. M., Huang, Y., Damste, J. S. S., Hopmans, E. C., and Cohen, A. S.: Northern Hemisphere Controls on Tropical Southeast African Climate During the Past 60000 Years, Science, 322, 252-255, doi:10.1126/science.1160485, 2008.

Tindall, J. C., Valdes, P. J., and Sime, L. C.: Stable water isotopes in HadCM3: Isotopic signature of El Niño-Southern Oscillation and the tropical amount effect, J. Geophys. Res., 114, D04111, doi:10.1029/2008JD010825, 2009.

Verschuren, D., Sinninghe Damste, J. S., Moernaut, J., Kristen, I., Blaauw, M., Fagot, M., and Haug, G. H.: Half-precessional dynamics of monsoon rainfall near the East African Equator, Nature, 462, 637-641, doi:10.1038/nature08520, 2009.

Vuille, M. and Werner, M.: Stable isotopes in precipitation recording South American summer monsoon and ENSO variabil- ity: observations and model results, Clim. Dyn., 25, 401-413, doi:10.1007/s00382-005-0049-9, 2005.

Vuille, M., Werner, M., Bradley, R. S., and Keimig, F.: Stable isotopes in precipitation in the Asian monsoon region, J. Geophys. Res.-Atmos., 110, D23108, doi:10.1029/2005JD006022, 2005.

Wagner, J. D. M., Cole, J. E., Beck, J. W., Patchett, P. J., Henderson, G. M., and Barnett, H. R.: Moisture variability in the southwestern United States linked to abrupt glacial climate change, Nature Geosci., 3, 110-113, doi:10.1038/ngeo707, 2010.

Wang, X., Auler, A. S., Edwards, R. L., Cheng, H., Cristalli, P. S., Smart, P. L., Richards, D. A., and Shen, C.-C.: Wet periods in northeastern Brazil over the past 210-kyr linked to distant climate anomalies, Nature, 432, 740-743, doi:10.1038/nature03067, 2004.

Wang, X., Auler, A. S., Edwards, R. L., Cheng, H., Ito, E., and Solheid, M.: Interhemispheric anti-phasing of rainfall during the last glacial period, Quaternary Sci. Rev., 25, 3391-3403, doi:10.1016/j.quascirev.2006.02.009, 2006.

Wang, Y., Cheng, H., Edwards, R. L., Kong, X., Shao, X., Chen, S., Wu, J., Jiang, X., Wang, X., and An, Z.: Millennial- and orbitalscale changes in the East Asian monsoon over the past 224000 years, Nature, 451, 1090-1093, doi:10.1038/nature06692, 2008.

Wang, Y. J., Cheng, H., Edwards, R. L., An, Z. S., Wu, J. Y., Shen, C. C., and Dorale, J. A.: A high-resolution absolute-dated late Pleistocene monsoon record from Hulu Cave, China, Science, 294, 2345-2348, doi:10.1126/science.1064618, 2001.

Webster, P. J., and Yang, S.: Monsoon and ENSO: Selectively interactive systems, Q. J. Roy. Metero. Soc., 118, 877-926, doi:10.1002/qj.49711850705, 1992.

Westaway, K. E., Zhao, J. X., Roberts, R. G., Chivas, A. R., Morwood, M. J., and Sutikna, T.: Initial speleothem results from western Flores and eastern Java, Indonesia: were climate changes from 47 to $5 \mathrm{ka}$ responsible for the extinction of Homo floresiensis?, J. Quaternary Sci., 22, 429-438, doi:10.1002/jqs.1122, 2007.

Xie, P. and Arkin, P. A.: Analyses of Global Monthly Precipitation Using Gauge Observations, Satellite Estimates, and Numerical Model Predictions, J. Climate, 9, 840-858, doi:10.1175/15200442(1996)009, 1996.

Yancheva, G., Nowaczyk, N. R., Mingram, J., Dulski, P., Schettler, G., Negendank, J. F. W., Liu, J., Sigman, D. M., Peterson, L. C., and Haug, G. H.: Influence of the intertropical convergence zone on the East Asian monsoon, Nature, 445, 74-77, doi:10.1038/nature05431, 2007.

Zhang, R. and Delworth, T. L.: Simulated tropical response to a substantial weakening of the Atlantic thermohaline circulation, J Climate, 18, 1853-1860, doi:1810.1175/JCLI3460.1851, 2005.

Zhou, H., Zhao, J., Feng, Y., Gagan, M. K., Zhou, G., and Yan, J.: Distinct climate change synchronous with Heinrich event one, recorded by stable oxygen and carbon isotopic compositions in stalagmites from China, Quaternary Res., 69, 306-315, doi:10.1016/j.yqres.2007.11.0012008.

Zimmermann, U., Ehhalt, D. H., and Munnich, K.: Soil-water movement and evapotranspiration, changes in the isotopic composition of the water, in: Isotopes in Hydrology, International Atomic Energy Agency, Vienna, Austria, 567-585, 1967. 